\title{
Steam Reforming of Model Bio-Oil Aqueous Fraction Using Ni-(Cu, Co, Cr)/SBA-15 Catalysts
}

\author{
José A. Calles *(1), Alicia Carrero, Arturo J. Vizcaíno *[D, Lourdes García-Moreno and \\ Pedro J. Megía
}

Chemical and environmental group, Rey Juan Carlos University, c/Tulipán, s/n, 28933 Mostoles, Spain; alicia.carrero@urjc.es (A.C.); lourdes.garcia@urjc.es (L.G.-M.); pedro.megia@urjc.es (P.J.M.)

* Correspondence: joseantonio.calles@urjc.es (J.A.C.); arturo.vizcaino@urjc.es (A.J.V.); Tel.: + 34-91-488-73-78 (J.A.C.); + 34-91-488-80-96 (A.J.V.)

Received: 26 October 2018; Accepted: 22 January 2019; Published: 25 January 2019

\begin{abstract}
Hydrogen obtained from biomass derivatives is considered a promising alternative to fossil fuels. The aim of this work is to test the viability of Ni-M/SBA-15 (M: Co, Cu, Cr) catalysts for the hydrogen production from bio-oil aqueous fraction reforming. Tests were performed in a fixed-bed reactor at $600{ }^{\circ} \mathrm{C}$ and atmospheric pressure. Firstly, the steam reforming (SR) of acetic acid, hydroxyacetone, furfural and phenol, as representative constituents of the bio-oil aqueous fraction, was carried out. Lower reactivity with increasing carbon number and decreasing steam-to-carbon ratio was observed. Coking rate during SR is a consequence of carbon number and aromaticity of the reactant, as well as the steam-to-carbon ratio. However, deactivation also depends on the graphitization degree of carbon filaments, higher in the case of coke formed from phenol. Then, the performance of the Ni-M/SBA-15 catalysts was studied in the reforming of a bio-oil aqueous fraction surrogate containing the four model compounds. Ni-Co/SBA-15 and Ni-Cr/SBA-15 samples were the most active because $\mathrm{Co}$ also catalyze the steam reforming reactions and $\mathrm{Cr}$ promotes the formation of very small $\mathrm{Ni}$ crystallites accounting for high conversion and the low coke deposition $(\sim 8$ times lower than Ni/SBA-15) in the form of poorly condensed carbon filaments.
\end{abstract}

Keywords: hydrogen production; hydroxyacetone; acetic acid; phenol; furfural; nickel; coke; thermodynamic equilibrium

\section{Introduction}

The continuous increase of energy demand based on fossil fuels has caused what is known as an energy problem, mainly characterized by [1-3]: (i) Limited energy resources: Society may face the premature depletion of fossil fuels. (ii) Economic factors: The disproportionate increase experienced in its extraction and use involves a continuous and irreversible trend in the growth of the costs of fossil fuels. (iii) Environmental impact: Negative environmental effects of global scope are linked to processing and consumption of energy from fossil fuels, which can be summarized in acid rain, climate change and destruction of the ozone layer, as well as acidification of soil and waters.

The international scientific community agrees that it is necessary to seek greater energy efficiency and energy models not based on fossil fuels. Therefore, increased diversification of sources, renewable energy and improving energy efficiency are major concerns [4-6].

Currently, research is guided to seek alternative energy resources that can replace existing sources completely or in part, provided they are clean, renewable and profitable [2,7]. Among these, biofuels and hydrogen have been highlighted to replace fossil fuels $[3,8,9]$. At the present time, hydrogen is considered an alternative fuel and its use is becoming more important. Hydrogen production has current interest in fuel cell applications, automobile applications and the production of electricity. 
Hydrogen is also used as a raw material in chemical synthesis and refining for the production of clean fuels. Currently, $97 \%$ of hydrogen production is achieved by steam reforming of natural gas and other fossil fuels [9]. However, different products derived from biomass, such as ethanol, glycerol or bio-oils, are alternatives for the production of hydrogen by steam reforming of oxygenated compounds [10-14]. The diversity of sources to obtain hydrogen makes it a promising energy vector and allows its production almost anywhere in the world.

In this context, bio-oils are a dark brown organic liquid from the pyrolysis of biomass, which contain numerous and complex oxygenate organic compounds, such as acids, alcohols, aldehydes, ketones, phenols and other oxygenates derived from biomass carbohydrates and lignin $[15,16]$. Bio-oils can be separated into two fractions: a water-insoluble phase and an aqueous phase. While the insoluble fraction can be used as a fuel and/or for the production of chemicals, the aqueous phase does not have many applications and it is discarded in most cases. This aqueous fraction contains water soluble oxygenates in total content between 15 and $60 \mathrm{wt} \%$, depending on the feedstock, operating conditions and the catalyst of the pyrolysis process. These factors also determine the necessity of water addition for phase separation [16,17]. Therefore, the catalytic steam reforming of this aqueous fraction of bio-oils could be an interesting way to valorize it and benefit the economics of bio-oil production [18].

Stoichiometrically, the steam reforming of oxygenates in the bio-oil aqueous fraction can be represented as follows:

$$
\mathrm{CH}_{\mathrm{x}} \mathrm{O}_{\mathrm{y}}+(2-y) \mathrm{H}_{2} \mathrm{O} \rightarrow \mathrm{CO}_{2}+(x / 2+2-y) \mathrm{H}_{2}
$$

The process is characterized by additional difficulties derived from the extremely heterogeneous composition of the bio-oil aqueous phase. This is the reason why researchers tend to use model compounds to study this process [19-24]. Among these, hydroxyacetone, acetic acid, phenol and furfural are good candidates, since acids are $19-25 \mathrm{wt} \%$, ketones are $12-20 \mathrm{wt} \%$, phenols are $1-5 \mathrm{wt} \%$ and furans are around $1 \mathrm{wt} \%$ of bio-oil [25], and thus they are generally major compounds in the aqueous fraction [26].

Steam reforming catalysts are usually based on supported nickel, but the main drawback of these materials is catalyst deactivation by carbon deposition. In order to reduce it, addition of promoters has been previously described in the literature. One strategy is the increase of the support basicity by adding alkaline $(\mathrm{Li}, \mathrm{K}, \mathrm{Na})$ or alkaline-earth $(\mathrm{Mg}, \mathrm{Ca})$ elements, in order to prevent carbon formation favored on acidic sites [17,27-32]. Lanthanides ( $\mathrm{La}, \mathrm{Ce}$ ) have also been reported to inhibit the carbon deposition on reforming catalysts' surface [17,32-35]. Another approach to improve steam reforming catalysts is the incorporation of a second transition metal. In this sense, $\mathrm{Ni}-\mathrm{Cu}$ bimetallic catalysts have been extensively studied in ethanol steam reforming, showing that $\mathrm{CO}$ production and coke deposition are decreased with the addition of certain loadings of $\mathrm{Cu}$ [36-38]. Several studies [39-42] have shown that $\mathrm{Ni}-\mathrm{Co}$ bimetallic catalysts are able to significantly decrease carbon deposition during the steam reforming reaction, and they have also increased activity and selectivity to $\mathrm{H}_{2}$ in steam reforming of oxygenates compounds. On the other hand, $\mathrm{Cr}$ addition has been claimed to be beneficial to reduce coke formation reactions [43,44] and inhibit the encapsulation of the nickel by carbon filaments [45], as well as suppress sintering of the active sites by dilution of the ensembles of Ni atoms [46,47], which in turn increases the stability of nickel catalysts.

Since the metal distribution over the support is important to obtain good conversion and selectivity to hydrogen, the choice of supports with highly developed surfaces to promote dispersion of the active metals is considered to be promising. Wang et al. [21] showed how the use of $\mathrm{Al}_{2} \mathrm{O}_{3}$ nano-rods as the support of $\mathrm{Ni}$ catalysts instead of commercial alumina led to superior performance in terms of activity and stability during steam reforming of bio-oil model compounds, attributed to higher metal dispersion. Yang et al. [48] demonstrated higher catalytic activity and stability of $\mathrm{Ni} / \mathrm{meso}-\mathrm{MgO}$ catalyst compared to conventional $\mathrm{Ni} / \mathrm{MgO}$. This is due to smaller and uniform Ni nanoparticles thanks to the high surface area and the confinement effect of the mesoporous structure of meso-MgO, which could effectively limit the growth of the active metal and stabilize Ni particles during the procedure of $\mathrm{NiO}$ reduction. SBA-15 is a mesostructured silica material with high specific surface area, 
narrow pore size distribution, and high thermal and hydrothermal stability, which has also exhibited enhanced reforming activity by improving Ni dispersion [36,37].

We recently demonstrated the benefits of adding a second metal to Ni/SBA-15-based catalysts on glycerol steam reforming [49]. Particularly, the novel Ni-Cr/SBA-15 catalyst exhibited considerably higher glycerol conversion and hydrogen production than the Ni/SBA-15 material with a drastic reduction in coke formation. However, to date, the reforming of the bio-oil aqueous fraction has not been studied on this kind of material.

Thus, the aim of this work is of this work is to test the viability of Ni-M/SBA-15 (M: Co, Cu, Cr) catalysts for the hydrogen production from bio-oil aqueous fraction reforming. Firstly, these catalysts have been tested in the steam reforming of single model compounds representative of the constituents of the bio-oil aqueous fraction - acetic acid, hydroxyacetone, furfural and phenol—with the aim of comparing how the reforming of each of these compounds proceeds, in terms of the products distribution (including coke formation) and conversion. Then, the prepared catalysts have been tested in the reforming of a bio-oil aqueous fraction surrogate containing the four model compounds, and the effect of the promoters' incorporation on the catalytic activity has been studied.

\section{Results and Discussion}

\subsection{Characterization of Fresh Catalysts}

The actual Ni loading and textural properties, mean Ni particle size, and reducibility properties of the fresh catalysts are summarized in Table 1. Detailed characterization of these materials has been published elsewhere [49]. Briefly, $\mathrm{N}_{2}$-adsorption analyses revealed that all materials exhibit type IV isotherms, typical of the pore mesostructure of the SBA-15 material used as the support. Incorporation of the second metal $(\mathrm{Cu}, \mathrm{Co}$ or $\mathrm{Cr})$ to Ni/SBA-15 just slightly decreased surface area (calculated according to Brunauer-Emmett-Teller-BET), pore volume and pore diameter. Only peaks corresponding to metallic Ni could be observed in the X-ray diffraction (XRD) patterns of all catalysts after reduction and the mean crystallites diameter $\left(\mathrm{D}_{\mathrm{Ni}}\right)$ calculated by applying the Scherrer equation is summarized in Table 1. It must be taken into account that, when applying the Scherrer formula to the calculation of the average crystallite size, from the full width at half maximum intensity (FWHM), smaller crystallites, which contribute mainly to the wings of the line profile, are scarcely taken into account and $\mathrm{D}_{\mathrm{Ni}}$ could be overestimated. The extreme limit of size that can be measured by XRD is $2 \mathrm{~nm}$ [50]. In any case, the addition of $\mathrm{Cu}, \mathrm{Co}$ and $\mathrm{Cr}$ to Ni/SBA-15 helps to form smaller Ni crystallites; the smallest are found in the Ni-Cr/SBA-15 sample.

From hydrogen temperature-programmed reduction $\mathrm{H}_{2}$-TPR analysis of the calcined samples (Figure 1), several reduction features are distinguised, which could be divided into two main regions: a low-temperature zone (below $400{ }^{\circ} \mathrm{C}$ ) that can be assigned to the reduction of metal oxide particles weakly interacting with the SBA-15; and a high-temperature zone (above $400{ }^{\circ} \mathrm{C}$ ), which includes the reduction of metal oxide species with strong interaction with the support. The contribution of each region to the reduction profile, obtained after deconvolution, is collected in Table 1. While $\mathrm{Ni}-\mathrm{Co} / \mathrm{SBA}-15$ showed a similar reduction profile to $\mathrm{Ni} / \mathrm{SBA}-15$, with around $30 \%$ of the reduction taking place above $400{ }^{\circ} \mathrm{C}$, the Ni-Cu/SBA- 15 sample could be almost completely reduced below $400{ }^{\circ} \mathrm{C}$. On the contrary, the main reduction of the Ni-Cr/SBA-15 catalyst $(83.5 \%)$ takes place above $400{ }^{\circ} \mathrm{C}$ and a higher temperature is needed to completely reduce it in comparison to the rest of samples. According to $\mathrm{H}_{2}$-TPR results, particles of $\mathrm{Ni}$ species strongly interacting with the support predominate in Ni-Cr/SBA-15 catalyst. 
Table 1. Physicochemical properties of the fresh catalysts.

\begin{tabular}{|c|c|c|c|c|c|c|c|c|}
\hline \multirow[t]{2}{*}{ Sample } & \multirow[t]{2}{*}{$\begin{array}{c}\mathrm{Ni}^{\mathrm{a}} \\
(w \mathrm{t} \%)\end{array}$} & \multirow{2}{*}{$\begin{array}{c}M^{a, b} \\
(w t \%)\end{array}$} & \multirow{2}{*}{$\begin{array}{c}S_{B E T} \\
\left(m^{2} g^{-1}\right)\end{array}$} & \multirow[t]{2}{*}{$\begin{array}{c}V_{\text {pore }}{ }^{c} \\
\left(\mathrm{~cm}^{3} \mathrm{~g}^{-1}\right)\end{array}$} & \multirow[t]{2}{*}{$\begin{array}{c}D_{\text {pore }}{ }^{d} \\
(\mathrm{~nm})\end{array}$} & \multirow[t]{2}{*}{$\begin{array}{l}D_{N i} e^{e} \\
(n m)\end{array}$} & \multirow{2}{*}{$\begin{array}{c}\text { TPR Profile } \\
<400{ }^{\circ} \mathrm{C} \\
\text { Area }(\%)\end{array}$} & \multirow{2}{*}{$\begin{array}{c}\text { TPR Profile } \\
>400{ }^{\circ} \mathrm{C} \\
\text { Area }(\%)\end{array}$} \\
\hline & & & & & & & & \\
\hline Ni/SBA-15 & $13.5 \pm 0.1$ & - & $521 \pm 4$ & $0.77 \pm 0.02$ & $8.3 \pm 0.1$ & $10.6 \pm 0.5$ & 69.8 & 30.2 \\
\hline Ni-Cu/SBA-15 & $15.0 \pm 0.1$ & $4 \pm 0.1$ & $485 \pm 1$ & $0.71 \pm 0.01$ & $8.1 \pm 0.1$ & $9.9 \pm 0.2$ & 99.0 & 1.0 \\
\hline Ni-Co/SBA-15 & $14.5 \pm 0.1$ & $4 \pm 0.1$ & $486 \pm 1$ & $0.72 \pm 0.02$ & $8.0 \pm 0.1$ & $9.0 \pm 0.3$ & 67.7 & 32.3 \\
\hline Ni-Cr/SBA-15 & $14.3 \pm 0.1$ & $3.6 \pm 0.1$ & $482 \pm 3$ & $0.68 \pm 0.03$ & $8.3 \pm 0.1$ & $5.8 \pm 0.1$ & 16.5 & 83.5 \\
\hline
\end{tabular}

${ }^{a}$ Measured by Inductively Coupled Plasma Atomic Emission Spectroscopy (ICP-AES); ${ }^{\mathrm{b}}$ M: Second metal (Cu, Co or $\mathrm{Cr}$ ); ${ }^{\mathrm{c}}$ Determined at $\mathrm{P} / \mathrm{P}_{0}=0.97 ;{ }^{\mathrm{d}}$ Maximum of the $\mathrm{BJH}$ (Barrett, Joyner and Halenda) pore size distribution;

${ }^{\mathrm{e}}$ Calculated from the (1 111 ) reflection of $\mathrm{Ni}$ in XRD of reduced catalysts.

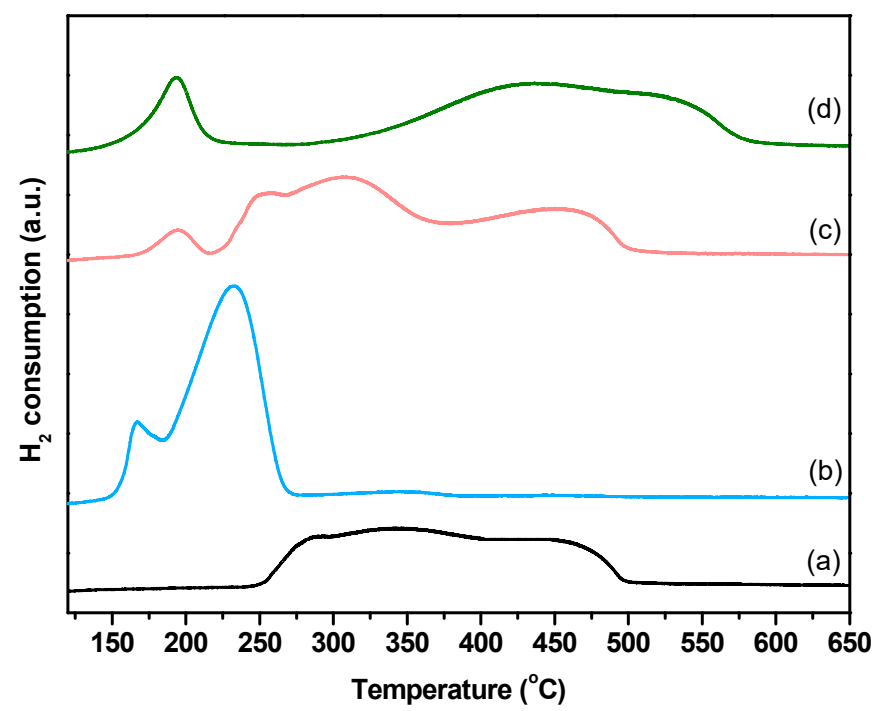

Figure 1. $\mathrm{H}_{2}$-TPR profiles of calcined catalysts: (a) Ni/SBA-15; (b) Ni-Cu/SBA-15; (c) Ni-Co/SBA-15; (d) Ni-Cr/SBA-15.

\subsection{Steam Reforming of Bio-Oil Aqueous Fraction Model Compounds}

\subsubsection{Thermodynamic Analysis of Steam Reforming of Model Compounds}

According to thermodynamic predictions, the complete conversion of each of the model compounds through steam reforming is reached at equilibrium in the whole temperatures range from 300 to $1000^{\circ} \mathrm{C}$. Figure 2 shows the equilibrium composition of the outlet stream (dry basis) when reforming is carried out with a water/model compound mixture similar to that experimentally used. Only $\mathrm{H}_{2}, \mathrm{CO}_{2}, \mathrm{CO}$ and $\mathrm{CH}_{4}$ are present in the gas phase. No formation of molecules with two or more carbons $\left(\mathrm{C}_{2+}\right)$ was predicted although side reactions may occur, since the energy of those molecules is generally higher than the energy of the final state, which is highly unstable under steam reforming conditions. Therefore, $\mathrm{C}_{2+}$ hydrocarbons are intermediate products in the reaction scheme which are absent in the reaction product stream at equilibrium conditions. This coincides with previous studies [51-53].

According to this, from the thermodynamics point of view, the steam reforming of the bio-oil aqueous fraction compounds can be represented by a combination of the following equations:

$$
\begin{gathered}
\text { Steam reforming: } \mathrm{CH}_{x} \mathrm{O}_{\mathrm{y}}+(1-y) \mathrm{H}_{2} \mathrm{O} \rightarrow \mathrm{CO}+(x / 2+1-y) \mathrm{H}_{2} \\
\text { Water-gas shift: } \mathrm{CO}+\mathrm{H}_{2} \mathrm{O} \rightarrow \mathrm{CO}_{2}+\mathrm{H}_{2} \\
\text { Methanation: } \mathrm{CO}+3 \mathrm{H}_{2} \rightarrow \mathrm{CH}_{4}+\mathrm{H}_{2} \mathrm{O} \\
\qquad \mathrm{CO}_{2}+4 \mathrm{H}_{2} \rightarrow \mathrm{CH}_{4}+2 \mathrm{H}_{2} \mathrm{O}
\end{gathered}
$$



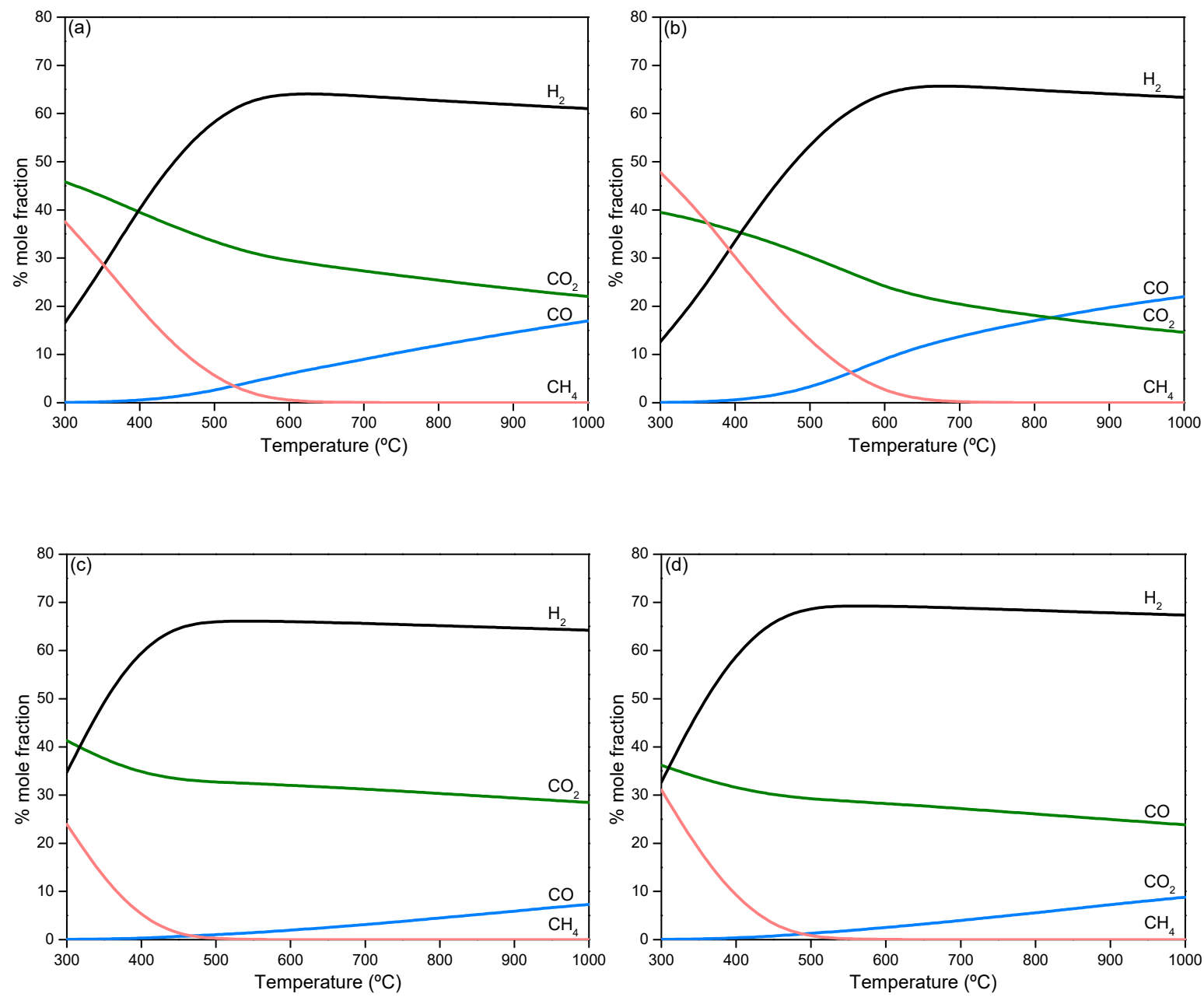

Figure 2. Thermodynamic prediction of equilibrium products' distribution with temperature in the steam reforming of acetic acid (a), hydroxyacetone (b), furfural (c) and phenol (d).

Regarding the evolution of products with temperature, in all cases, the hydrogen content in the outlet stream increases with temperature, as the methane content decreases, to reach a maximum. This is caused by steam reforming (Equation (2)) being favored as temperature increases, because this is an endothermal reaction while methanation reactions (Equations (4) and (5)) are unfavored, as they are highly exothermal. Since water-gas shift (Equation (3)) is an exothermal reaction, the CO mol \% increases at the expense of $\mathrm{CO}_{2}$ as the temperature increases, consuming also $\mathrm{H}_{2}$ (reverse reaction). This leads to the decrease of the $\mathrm{H}_{2}$ content above a temperature at which methanation is almost completely unflavoured $\left(\mathrm{CH}_{4}\right.$ content below $\left.0.2 \mathrm{~mol} \%\right)$.

The maximum $\mathrm{H}_{2}$ production at equilibrium, as well as the temperature at which it is reached, depends on the compound fed to reforming and the steam/carbon ratio (S/C). The highest $\mathrm{H}_{2}$ content in the product stream $(69.2 \mathrm{~mol} \%)$ is reached by phenol steam reforming at $565{ }^{\circ} \mathrm{C}$. According to the stoichiometry of the global reforming reaction of each of the compounds (Equations (6)-(9)), $70 \mathrm{~mol} \%$ $\mathrm{H}_{2}$ could be reached by phenol and hydroxyacetone SR, while $66.7 \mathrm{~mol} \% \mathrm{H}_{2}$ would be expected for acetic acid and furfural SR.

$$
\text { Acetic acid SR: } \mathrm{C}_{2} \mathrm{H}_{4} \mathrm{O}_{2}+2 \mathrm{H}_{2} \mathrm{O} \rightarrow 2 \mathrm{CO}_{2}+4 \mathrm{H}_{2}
$$

Hydroxyacetone SR: $\mathrm{C}_{3} \mathrm{H}_{6} \mathrm{O}_{2}+4 \mathrm{H}_{2} \mathrm{O} \rightarrow 3 \mathrm{CO}_{2}+7 \mathrm{H}_{2}$

$$
\text { Furfural SR: } \mathrm{C}_{5} \mathrm{H}_{4} \mathrm{O}_{2}+8 \mathrm{H}_{2} \mathrm{O} \rightarrow 5 \mathrm{CO}_{2}+10 \mathrm{H}_{2}
$$




$$
\text { Phenol SR: } \mathrm{C}_{6} \mathrm{H}_{6} \mathrm{O}+11 \mathrm{H}_{2} \mathrm{O} \rightarrow 6 \mathrm{CO}_{2}+14 \mathrm{H}_{2}
$$

The fact that lower $\mathrm{H}_{2}$ content is achieved with hydroxyacetone than phenol or even furfural is due to the lower S/C fed to the reactor, which limits steam reforming and water-gas shift reactions and favors methanation. In addition, temperature at which maximum $\mathrm{H}_{2}$ production takes place is in the range $550-700{ }^{\circ} \mathrm{C}$, the lowest temperature corresponding to phenol and furfural SR due to the high $\mathrm{S} / \mathrm{C}$. On the basis of these results, a temperature of $600^{\circ} \mathrm{C}$ was selected to perform the catalytic tests using the Ni-M/SBA-15 catalysts. The same temperature was used for both the steam reforming of model compounds and the simulated bio-oil aqueous phase in order to extract valuable conclusions regarding the interaction between the different reactants in the mixture.

\subsubsection{Steam Reforming of Model Compounds on Ni-M/SBA-15 Catalysts}

The results obtained in the steam reforming of the different model compounds using the prepared catalysts are shown in Figures 3 and 4, in terms of conversion and product distribution in the gas stream, respectively. In all cases, the tested catalysts kept conversions above $95 \%$ under the present operation conditions, except for the Ni-Cu/SBA-15 sample, which clearly suffers from deactivation. In general, conversions were higher in the steam reforming of acetic acid (AA) and furfural (Fur), while the steam reforming of hydroxyacetone (HA) led to lower conversion, coinciding with the highest loss of activity of the Ni-Cu/SBA-15 sample. Ni-Co/SBA-15 and Ni-Cr/SBA-15 were the most active samples. This may be ascribed to the smaller Ni crystallites' size, especially in the Ni-Cr/SBA-15 sample (see Table 1), and the presence of Co, which is known for its reforming activity [11], in the $\mathrm{Ni}-\mathrm{Co} / \mathrm{SBA}-15$ catalyst. Comparing feedstocks with similar S/C ratio, in order to exclude the positive effect of water excess, AA $(\mathrm{S} / \mathrm{C}=4)$ is more easily reformed than $\mathrm{HA}(\mathrm{S} / \mathrm{C}=2.67)$ while furfural $(S / C=13.2)$ is easier to convert than phenol $(S / C=11)$. This indicates a decrease in reactivity with increasing carbon number, in agreement with Trane-Restrup et al. [54]. Although the $\mathrm{C}-\mathrm{C}$ bonds in aromatic compounds (Fur and $\mathrm{Ph}$ ) are more stable than in AA or HA, which may result in lower reactivity [21], the higher $\mathrm{S} / \mathrm{C}$ ratio used with those promoted higher conversion.

The main products obtained in the gas stream were $\mathrm{H}_{2}, \mathrm{CO}_{2}, \mathrm{CO}$ and $\mathrm{CH}_{4}$ (Figure 4). Only acetone could be detected as an intermediate in the condensate stream of AA and HA steam reforming but with concentrations lower than $0.1 \mathrm{wt} \%$ and $0.7 \mathrm{wt} \%$, respectively. This intermediate could be formed by ketonization of acetic acid or hydrodeoxygenation of hydroxyacetone, but its low concentration indicates that it was almost fully converted to hydrogen and carbon oxides, because as predicted by thermodynamics (Section 2.2.1), it should be highly unstable under our reaction conditions.

In the case of AA steam reforming, the hydrogen content in the gas stream ranges between 55 (Ni-Cu/SBA-15) and $60 \mathrm{~mol} \%$ (Ni/SBA-15, Ni-Co/SBA-15 and Ni-Cr/SBA-15), relatively close to the equilibrium value, $63.9 \mathrm{~mol} \%$. $\mathrm{CH}_{4}$ formation is low ( $\left.<1.8 \mathrm{~mol} \%\right)$, but slightly higher than the equilibrium value, while $\mathrm{CO}$ and $\mathrm{CO}_{2}$ are the main $\mathrm{C}_{1}$ products with $\mathrm{CO}_{2} / \mathrm{CO}$ ratios below equilibrium. This may indicate that both $\mathrm{CH}_{4}$ and $\mathrm{CO}$ are intermediates in the AA steam reforming pathway, while $\mathrm{CO}_{2}$ should be a final product. This can be explained by decomposition (Equation (10)) or decarboxylation (Equation (11)) of AA, followed by methane steam reforming (Equation (12)) and water-gas shift (Equation (5)), taking place in a more complex pathway than the general one proposed from the thermodynamic analysis (Equations (2)-(5)), where $\mathrm{CH}_{4}$ was formed from the products of steam reforming through methanation reaction unfavored at high temperatures.

$$
\begin{gathered}
\text { Decomposition of AA: } \mathrm{CH}_{3} \mathrm{COOH} \rightarrow 2 \mathrm{CO}+2 \mathrm{H}_{2} \\
\text { Decarboxilation of AA: } \mathrm{CH}_{3} \mathrm{COOH} \rightarrow \mathrm{CH}_{4}+\mathrm{CO}_{2} \\
\text { Methane SR: } \mathrm{CH}_{4}+\mathrm{H}_{2} \mathrm{O} \rightarrow 3 \mathrm{H}_{2}+\mathrm{CO}
\end{gathered}
$$




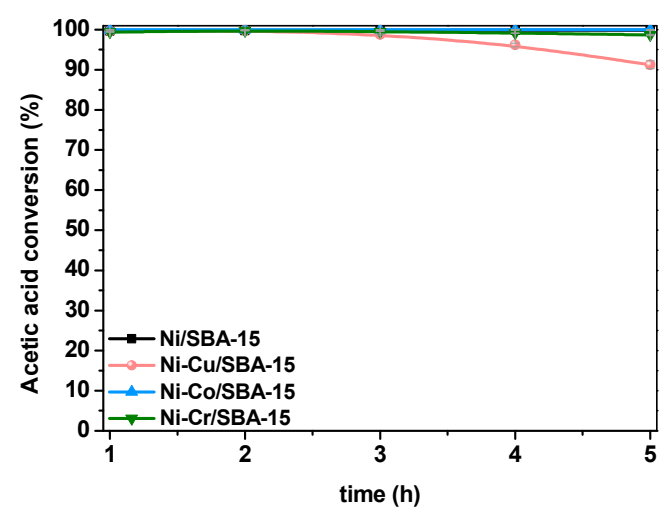

(a)

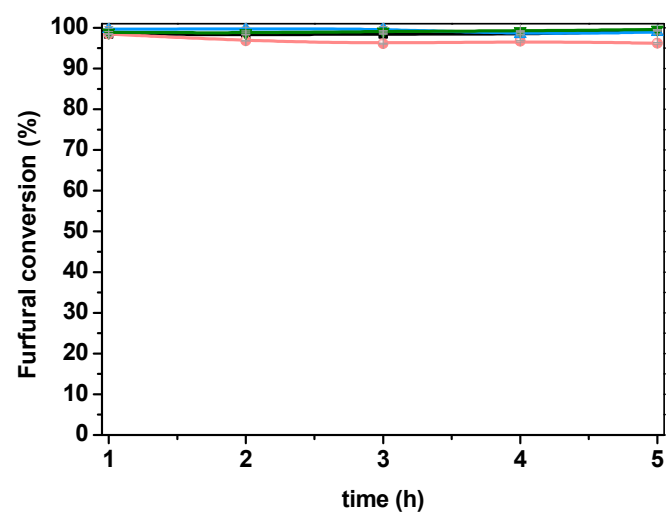

(c)

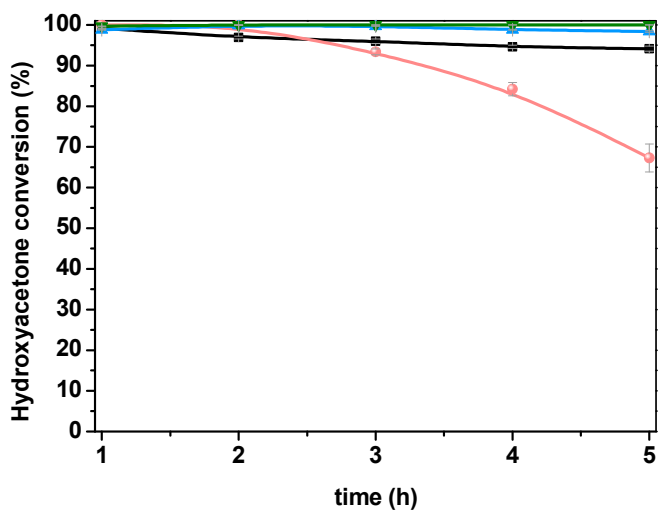

(b)

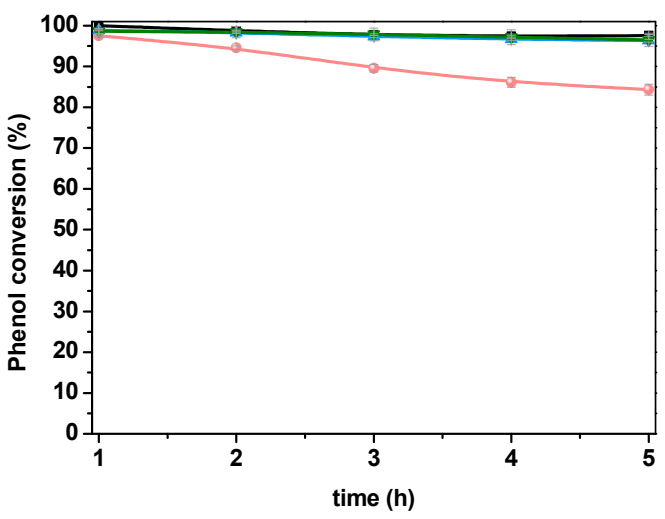

(d)

Figure 3. Evolution of conversion with time during the steam reforming of acetic acid (a), hydroxyacetone (b), furfural (c) and phenol (d) over Ni-M/SBA-15 catalysts.

Decarboxylation and decomposition are side reactions based on a mechanism of dissociative adsorption of AA on the catalyst to form acetate $\left(\mathrm{CH}_{3} \mathrm{COO}^{*}\right)$ and / or acyl $\left(\mathrm{CH}_{3} \mathrm{CO}^{*}\right)$ species, which decompose to lead to the formation of methyl species $\left(\mathrm{CH}_{3}^{*} ; x \leq 3\right)$ with release of $\mathrm{CO}_{2}$ and $\mathrm{CO}$, respectively. Depending on the reaction conditions (temperature, $\mathrm{S} / \mathrm{C}$ ratio, $\mathrm{H}_{2}$ concentration, etc.) and the catalyst surface, the methyl species can either be hydrogenated to $\mathrm{CH}_{4}$ or cleave off further $\mathrm{H}$ atoms $\left(\mathrm{CH}_{3}{ }^{*} \rightarrow \mathrm{CH}_{\mathrm{x}}{ }^{*} ; x<3\right)[55,56]$. The remaining carbon would react with hydroxyl groups from the dissociative adsorption $\mathrm{H}_{2} \mathrm{O}$ on the catalyst, forming $\mathrm{H}_{2}$ and $\mathrm{CO}$; otherwise, carbon deposition would occur. According to our results, only a small fraction of methyl species is hydrogenated to $\mathrm{CH}_{4}$ under the present conditions. Instead, steam reforming reactions are favored on the Ni/SBA-15-based catalysts at $600{ }^{\circ} \mathrm{C}$ and $\mathrm{S} / \mathrm{C}$ ratio $=4$.

The $\mathrm{CO}_{2} / \mathrm{CO}$ ratio lower than equilibrium would confirm that $\mathrm{CO}$ is the primary product of steam reforming reactions, further being converted into $\mathrm{CO}_{2}$ by water-gas shift. While the rest of samples achieved $\mathrm{CO}_{2} / \mathrm{CO}$ ratios higher than 4.0 , the less active Ni-Cu/SBA-15 sample led to a $\mathrm{CO}_{2} / \mathrm{CO}$ ratio lower than 3.4. In addition, for this catalyst, a trace amount of acetone (less than $0.1 \mathrm{wt} \%$ ) was detected in the liquid outlet stream, indicating that ketonization of acetic acid (Equation (13)) also occurred during the steam reforming process. Acetone can further undergo steam reforming (Equation (14)) or, on the contrary, it can polymerize by aldol condensation to form coke deposits (Equation (15)). Although dehydration to ketene (Equation (16)) has also been described to occur during AA steam reforming, no evidence of such reaction was observed in this work, which may be ascribed to the low acidity of these catalysts, since dehydration is usually favored on acidic materials [57]. The absence 
of ketene in the gas phase products implies that ketene is a surface intermediate readily reacting further [55], probably through steam reforming (Equation (17)).

$$
\begin{gathered}
\text { Ketonization of AA: } 2 \mathrm{CH}_{3} \mathrm{COOH} \rightarrow \mathrm{CH}_{3} \mathrm{COCH}_{3}+\mathrm{CO}_{2}+\mathrm{H}_{2} \mathrm{O} \\
\text { Acetone steam reforing: } \mathrm{CH}_{3} \mathrm{COCH}_{3}+2 \mathrm{H}_{2} \mathrm{O} \rightarrow 3 \mathrm{CO}+5 \mathrm{H}_{2} \\
\text { Acetone polymerization: } \mathrm{CH}_{3} \mathrm{COCH}_{3} \rightarrow \text { oligomerization } \rightarrow \text { coke } \\
\text { Dehydration of AA: } \mathrm{CH}_{3} \mathrm{COOH} \rightarrow \mathrm{CH}_{2} \mathrm{CO}+\mathrm{H}_{2} \mathrm{O} \\
\text { Ketene steam reforming: } \mathrm{CH}_{2} \mathrm{CO}+\mathrm{H}_{2} \mathrm{O} \rightarrow 2 \mathrm{CO}+2 \mathrm{H}_{2}
\end{gathered}
$$

Since ketonization and decomposition reactions occur in parallel with the steam reforming, the hydrogen production is lower for the Ni-Cu/SBA-15 catalyst, which shows poorer activity for AA steam reforming. The rest of samples reached similar hydrogen production.

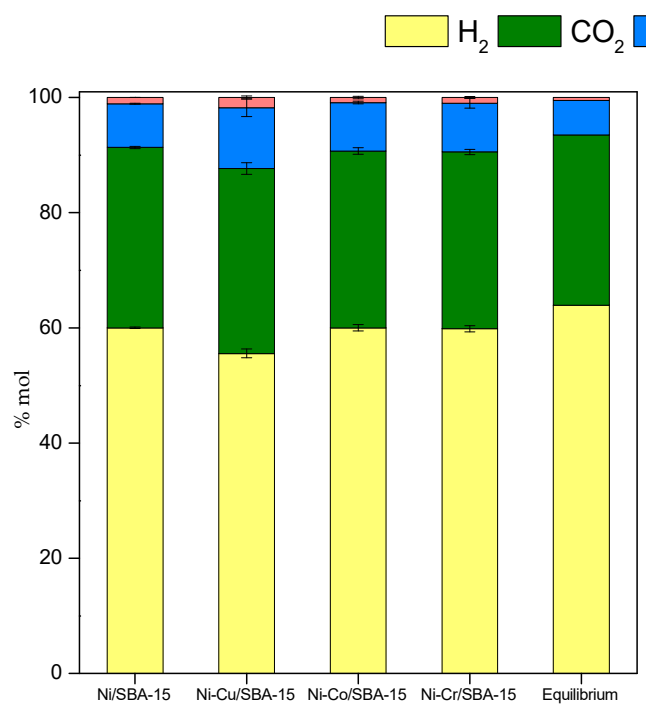

(a)

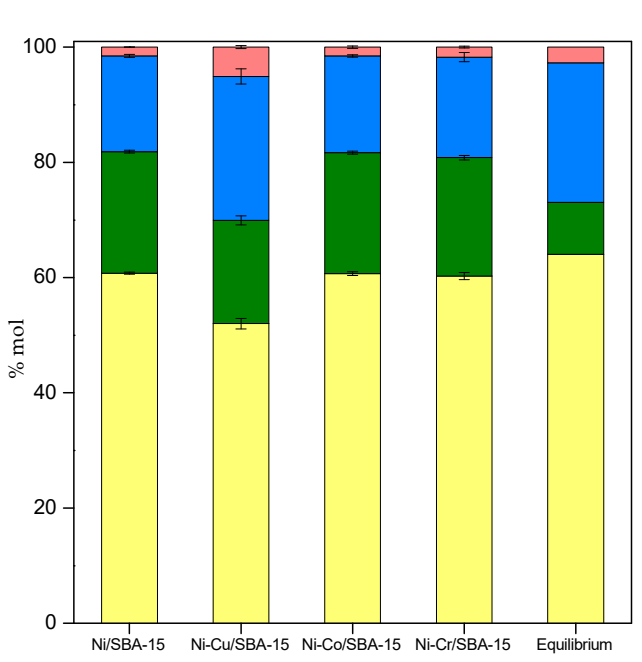

(b)

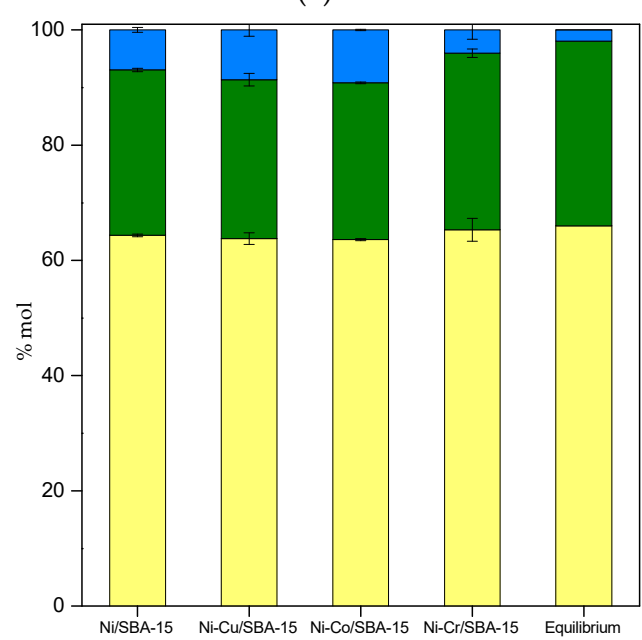

(c)

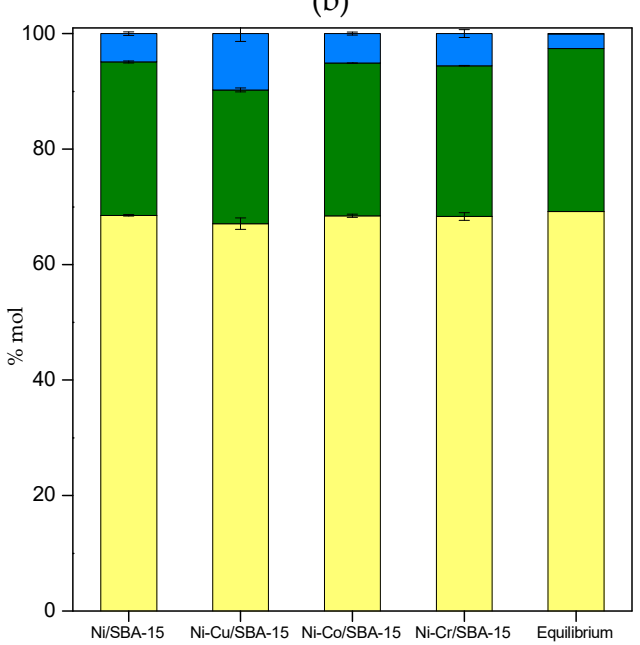

(d)

Figure 4. Gaseous products distribution (dry basis) from steam reforming of (a) acetic acid, (b) hydroxyacetone, (c) furfural and (d) phenol over Ni-M/SBA-15 catalysts.

Similar results were obtained in the HA steam reforming, with hydrogen contents in the gas stream between 52 (Ni-Cu/SBA-15) and $61 \mathrm{~mol} \%$ (Ni/SBA-15, Ni-Co/SBA-15 and Ni-Cr/SBA-15), the 
equilibrium value being $64.0 \mathrm{~mol} \% . \mathrm{CO}$ and $\mathrm{CO}_{2}$ are the main $\mathrm{C}_{1}$ products with $\mathrm{CO}_{2} / \mathrm{CO}$ ratios below half the equilibrium value. On the other hand, contrary to the case of $\mathrm{AA}$, the $\mathrm{CH}_{4}$ content in the gas phase is slightly lower than equilibrium prediction, except for the Ni-Cu/SBA-15 sample. Again, it can be explained by a reaction network more complex than that extracted from the thermodynamic analysis (Equations (2)-(5)). Methane can be formed by HA decomposition (Equation (18)), maybe occurring in several steps implying some intermediates. Since acetone was detected in the condensate phase, the hydrodeoxygenation of HA (Equation (19)) should be taking place in parallel to steam reforming, and acetone decomposition (Equation (20)) would lead to $\mathrm{CH}_{4}$ formation. Although it is accompanied by ketene formation, the fact that ketene was not detected among the products may be explained by its high reactivity, probably through steam reforming according to (Equation (17)).

$$
\begin{gathered}
\text { Ketene steam reforming: } \mathrm{CH}_{2} \mathrm{CO}+\mathrm{H}_{2} \mathrm{O} \rightarrow 2 \mathrm{CO}+2 \mathrm{H}_{2} \\
\text { Decomposition of HA: } \mathrm{CH}_{3} \mathrm{COCH}_{2} \mathrm{OH} \rightarrow \mathrm{CH}_{4}+2 \mathrm{CO}+\mathrm{H}_{2} \\
\text { Hydrodeoxygenation of HA: } \mathrm{CH}_{3} \mathrm{COCH}_{2} \mathrm{OH}+\mathrm{H}_{2} \rightarrow \mathrm{CH}_{3} \mathrm{COCH}_{3}+\mathrm{H}_{2} \mathrm{O} \\
\text { Acetone decomposition: } \mathrm{CH}_{3} \mathrm{COCH}_{3} \rightarrow \mathrm{CH}_{2} \mathrm{CO}+\mathrm{CH}_{4}
\end{gathered}
$$

According to Wang et al. [56], the decomposition mechanism of HA starts with the formation of $\mathrm{CH}_{3} \mathrm{COCH}_{2} \mathrm{O}^{*}$ or $\mathrm{CH}_{3} \mathrm{COCH}_{2}{ }^{*}$ species. The latter could form acetone by hydrogenation [58]. However, the most likely reaction pathway involves the $\mathrm{CH}_{3} \mathrm{COCH}_{2} \mathrm{O}^{*}$ species, further decomposing to methyl species $\left(\mathrm{CH}_{3}{ }^{*}\right)$ through several steps implying acyl $\left(\mathrm{CH}_{3} \mathrm{CO}^{*}\right)$ species, similarly to AA decomposition but with no expected $\mathrm{CO}_{2}$ release. Catalyst and operating conditions would determine $\mathrm{CH}_{4}$ formation by $\mathrm{CH}_{3}{ }^{*}$ hydrogenation or $\mathrm{H}_{2}$ and $\mathrm{CO}$ generation by cleavage of $\mathrm{C}-\mathrm{H}$ bonds of $\mathrm{CH}_{3}{ }^{*}$ and interaction of the remaining carbon precursor with $\mathrm{OH}^{*}$ or $\mathrm{O}^{*}$ intermediates formed from $\mathrm{H}_{2} \mathrm{O}$ decomposition. In this case, the low $\mathrm{CH}_{4}$ content among the gas products and the high carbon oxides formation indicate that these $\mathrm{Ni} / \mathrm{SBA}-15$-based catalysts favored steam reforming reactions over decomposition of HA under the present operating conditions. However, poorer activity of Ni-Cu/SBA-15 sample, as shown in Figure $3 b$, led to higher $\mathrm{CH}_{4}$ formation, lower $\mathrm{CO}_{2} / \mathrm{CO}$ ratio and, consequently, lower $\mathrm{H}_{2}$ production than the rest of samples.

Finally, in the steam reforming of Fur and $\mathrm{Ph}$, only $\mathrm{H}_{2}, \mathrm{CO}_{2}$ and $\mathrm{CO}$ were detected as reaction products. The absence of $\mathrm{CH}_{4}$ in the products stream is ascribed to the high $\mathrm{S} / \mathrm{C}$ ratio and the fact that there is no $\mathrm{CH}_{3}$ group in the structure of Fur and $\mathrm{Ph}$ [59]. This implies that $\mathrm{CO}_{\mathrm{x}}$ formation by steam reforming of $\mathrm{CH}^{*}$ or $\mathrm{C}^{*}$ species formed from the decomposition of the Fur or Ph ring [60] is more favored than the hydrogenation of those intermediate species to $\mathrm{CH}_{4}$ in these reaction conditions. In addition, although methanation could take place according to the reactions scheme suggested for the equilibrium calculations (Equations (4) and (5)), this reaction is disfavored at $600{ }^{\circ} \mathrm{C}$ due to its exothermicity. Regarding hydrogen production, the equilibrium concentration is nearly reached in both Fur and Ph steam reforming. The slight differences in hydrogen formation are in line with the $\mathrm{CO}_{2} / \mathrm{CO}$ ratio, so that the higher the ratio the higher the hydrogen content among the products. Contrary to the previous feedstocks, despite the lower conversion of the Ni-Cu/SBA-15 catalysts in the Fur and Ph steam reforming (Figure 3), the hydrogen content is also near the equilibrium prediction. This is probably a consequence of the favorable reaction conditions derived from the high S/C ratio used with these reactants as a consequence of their low solubility.

\subsubsection{Coke Formation during the Steam Reforming of Model Compounds on Ni-M/SBA-15 Catalysts}

All the used catalysts were analyzed by thermogravimetric analyses (TGA) in order to determine coke deposition and coking rates summarized in Table 2. Independently of the model compound fed in the steam reforming test, the coking rate varies in the order: Ni-Cu/SBA-15 > Ni/SBA-15 > Ni-Co/SBA-15 > Ni-Cr/SBA-15. 
Table 2. Coke formation rate $\left(\mathrm{mg} / \mathrm{g}_{\text {cat }} \cdot \mathrm{h}\right)$ in the steam reforming of hydroxyacetone $(\mathrm{HA})$, acetic acid (AA), phenol (Ph) and furfural (Fur) using the Ni-M/SBA-15 catalysts.

\begin{tabular}{ccccc}
\hline Catalyst & AA & HA & Fur & Ph \\
\hline Ni/SBA-15 & $44.8 \pm 0.5$ & $96.3 \pm 1.0$ & $21.2 \pm 0.2$ & $14.1 \pm 0.2$ \\
Ni-Cu/SBA-15 & $154.0 \pm 1.6$ & $165.0 \pm 1.8$ & $96.7 \pm 1.1$ & $19.8 \pm 0.2$ \\
Ni-Co/SBA-15 & $35.8 \pm 0.4$ & $77.0 \pm 0.8$ & $9.2 \pm 0.1$ & $9.0 \pm 0.2$ \\
Ni-Cr/SBA-15 & $3.5 \pm 0.1$ & $18.3 \pm 0.2$ & $2.6 \pm 0.1$ & $7.0 \pm 0.2$ \\
\hline
\end{tabular}

It is noticeable that the coking resistance of $\mathrm{Ni}-\mathrm{Cr} / \mathrm{SBA}-15$ decreases by 2 (Ph) to 13 (AA) times the amount of coke formed over our reference material Ni/SBA-15. This is mainly attributed to the small Ni crystallites in this sample which avoid the formation of the intermediary surface species of coke deposition [30]. The presence of $\mathrm{Co}$, which is less prone to coke accumulation than $\mathrm{Ni}$ [11], would explain the also high coking resistance of the Ni-Co/SBA-15 sample. On the contrary, enhancement of the carbon formation mechanism has been reported at certain $\mathrm{Cu}$ loadings in $\mathrm{Cu}-\mathrm{Ni}$ catalysts [61], which accounts for the Ni-Cu/SBA-15 sample leading to the highest coke deposition. This sample also showed a decrease of conversion relative to time-on-stream (see Figure 3), which would indicate a relationship between the amount of coke formed and deactivation. Since this effect was more noticeable in the HA steam reforming, the corresponding derivative thermograms are shown in Figure 5. All the samples show a wide Derivative Thermogravimetry (DTG) profile between 450 and $625^{\circ} \mathrm{C}$ with maximum carbonaceous matter combustion rate taking place between 536 and $565{ }^{\circ} \mathrm{C}\left(\mathrm{T}_{\max }\right)$. These temperatures are in accordance with the combustion of filamentous coke typically formed over Ni catalysts during steam reforming $[29,30]$ and the wide profile indicates the presence of carbonaceous species with different ordering degree. Concretely, in the case of Ni/SBA-15 and Ni-Cu/SBA-15 samples, two regions can be distinguished. Peaks at lower temperature correspond to less ordered carbon while those at $565{ }^{\circ} \mathrm{C}$ indicate higher graphitization degree of the carbon species. The characteristics of the coke deposited in steam reforming is a result of a balance between its formation and its elimination by gasification, which depends on the operating conditions, time-on-stream and the catalyst employed [62]. As coke is formed, it evolves from amorphous towards filamentous coke, which progressively undergoes condensation, increasing its ordering degree and finally leading to graphitic coke [63], which has been described as the cause of deactivation by blocking the Ni particles. Thus, the peak at lower temperature in the DTG profile of Ni-Cu/SBA-15 may be ascribed to incipient structures of filamentous coke, still present as a consequence of the high carbon formation rate of this catalyst, while the peak at $565{ }^{\circ} \mathrm{C}$ may be ascribed to aged filaments in the form of a more graphitic coke, which burns at higher temperature. The presence of this aged coke is the cause for the loss of conversion with time of Ni-Cu/SBA-15 sample. Similarly, the peak of this more graphitic coke can be observed in the profile of Ni/SBA-15 sample, but in lower proportion, which would account for the slight deactivation observed in this catalyst.

Regarding carbon deposition from different feedstocks, Table 2 shows that the coking rate varies in the order: $\mathrm{HA}>\mathrm{AA}>\mathrm{Fur}>\mathrm{Ph}$. It has been stated that carbon formation in steam reforming is largest for olefins and aromatics and also larger for large molecules compared with smaller ones [13]. However, coke deposition depends on the S/C ratio since higher steam content in the feed should favour gasification of carbonaceous material. Given the significantly higher S/C ratio used with in $\mathrm{Ph}$ and Fur, the higher coking rate in HA and AA steam reforming can be explained. It is interesting to note that, although the lowest coke amount was formed with $\mathrm{Ph}$, deactivation was more severe than that of steam reforming of Fur or even AA. Thus, the nature of coke should depend on the feedstock. Figure 6 shows the derivative thermograms of the used $\mathrm{Ni}-\mathrm{Cu} / \mathrm{SBA}-15$ sample. The maximum carbon oxidation temperatures $\left(\mathrm{T}_{\max }\right)$ correspond to filamentous coke in all cases, but different peaks corresponding to various ordering degrees can be observed depending on the steam reforming feedstock. The peak assigned to a more graphitic coke is the only one that can be observed $\left(\mathrm{T}_{\max }=569^{\circ} \mathrm{C}\right)$ in the Ph steam reforming, while the peak assigned to a poorly evolved coke $\left(\mathrm{T}_{\max }=528^{\circ} \mathrm{C}\right)$ is predominant in the Fur 
steam reforming. This could be related with the loss of activity observed with $\mathrm{Ph}$ as opposed to Fur steam reforming.

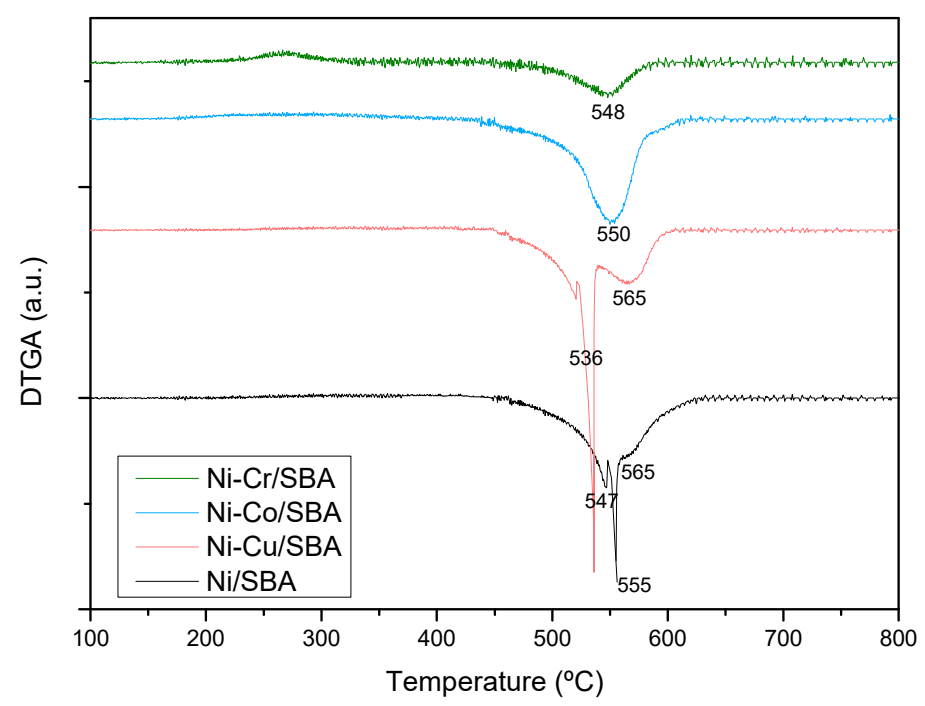

Figure 5. Derivative thermogravimetric analyses (airflow) of the Ni-M/SBA-15 catalysts used in steam reforming of hydroxyacetone.

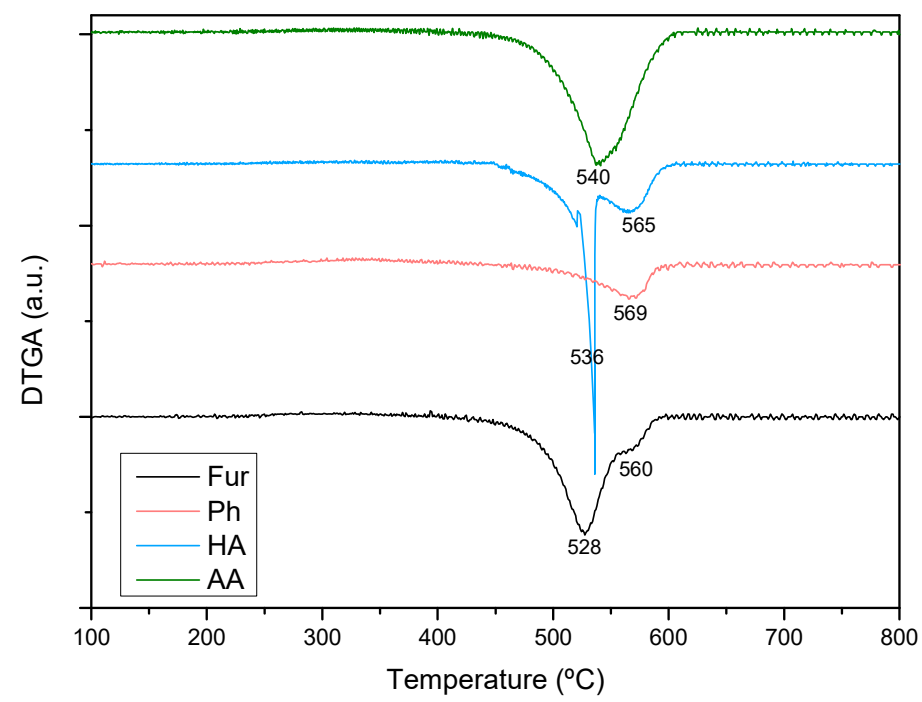

Figure 6. Derivative thermogravimetric analyses (airflow) of the Ni-Cu/SBA- 15 catalyst used in steam reforming of different feedstocks.

\subsection{Steam Reforming of Model Bio-Oil Aqueous Fraction}

The Ni-M/SBA-15 catalysts were finally tested in the steam reforming of a bio-oil aqueous fraction surrogate at $600{ }^{\circ} \mathrm{C}$. The feed for these tests consisted of an aqueous mixture of the model compounds studied in Section 2.2 simulating the aqueous fraction obtained in the catalytic fast-pyrolysis of de-ashed wheat straw as reported in reference H-ZSM-5 [16]. Typically, bio-oil is recovered as a complex mixture needing water addition for phase segregation and so leading to water contents around $80 \mathrm{wt} \%$ in the aqueous fraction [17,64]. In our case, the water content is relatively low (41 wt \%) since two phases were directly obtained in the pyrolysis process and could be separated without extra water addition. The advantage of this low water content in the bio-oil aqueous fraction is that the S/C ratio can be adjusted by a simple water addition step. Consequently, the composition of the aqueous fraction used in this work was $31 \mathrm{wt} \%$ acetic acid, $18 \mathrm{wt} \%$ hidroxyacetone, $6 \mathrm{wt} \%$ furfural and $4 \mathrm{wt} \%$ 
phenol in water. The S/C molar ratio corresponding to this feed is 0.95 , while the stoichiometric $\mathrm{S} / \mathrm{C}$ ratio would be 1.28, according to Equation (1). No S/C ratio adjustment was carried out in order to work under harsh operation conditions during the steam reforming, allowing the observation of clear differences in the performance of each catalyst (conversion, product distribution and coke formation) at $5 \mathrm{~h}$ time-on-stream (TOS).

Regarding conversion, Figure 7 displays the evolution with time-on-stream of the carbon conversion $\left(\mathrm{X}_{\mathrm{C}}\right)$, calculated from the flowrates of carbon fed $\left(\mathrm{F}_{\mathrm{C}, \text { feed }}\right)$ and carbon in the condensate product stream $\left(\mathrm{F}_{\mathrm{C}, \text { condensate }}\right)$, as follows:

$$
\mathrm{X}_{\mathrm{C}}(\%)=\frac{F_{C, \text { feed }}-F_{C, \text { condensate }}}{F_{C, \text { feed }}} \cdot 100
$$

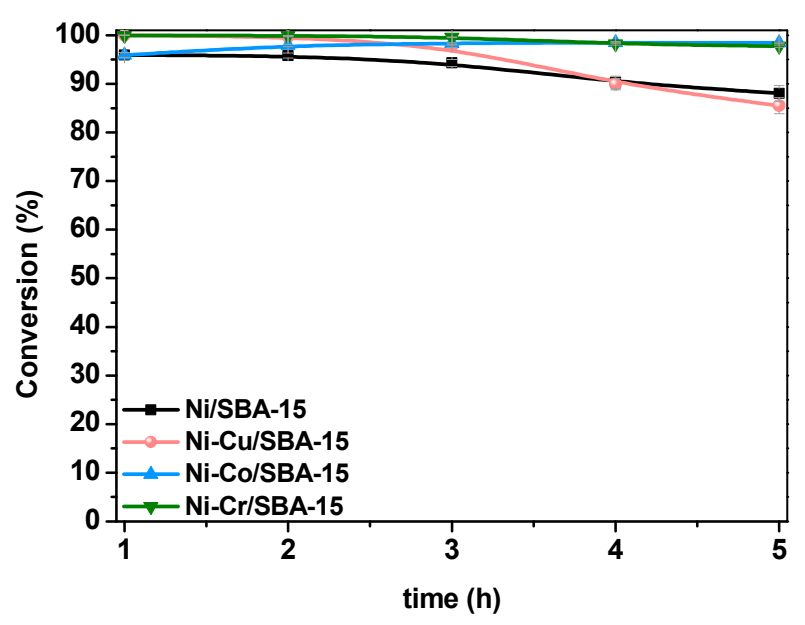

Figure 7. Carbon conversion in the reforming of model bio-oil aqueous fraction over Ni-M/ SBA-15 catalysts.

As expected, differences among the various catalysts are highlighted when using an adverse $\mathrm{S} / \mathrm{C}$ ratio. While Ni-Co/SBA-15 and Ni-Cr/SBA-15 maintained carbon conversion above $97 \%$, deactivation of Ni/SBA-15 and Ni-Cu/SBA-15 could be observed within $5 \mathrm{~h}$ TOS. This result is in line with those obtained in the steam reforming of the single model compounds, mainly in the HA reforming where deactivation could be noticed due to high coke deposition. The reason for the higher activity, as mentioned before, is the presence of $\mathrm{Co}$ as an additional active metal in Ni-Co/SBA-15 catalyst and the small $\mathrm{Ni}$ crystallites in the Ni-Cr/SBA-15 sample. The improvement of the Ni dispersion by $\mathrm{Cr}$ addition has been described to be caused by inhibition of the enlargement of Ni particles during thermal processes (calcination, reduction or even reaction), since chromium oxide can act as a structural promoter $[44,46]$. Some studies suggest that the $\mathrm{Cr}$ species distribute on or surrounding the Ni surface, and thus the Ni particles should be much more difficult to move or sinter under thermal conditions $[47,65]$. Decrease in size of the Ni crystallites due to the structural promoting effect of chromia induces an increase of the number of such active centers, which in turns increases the reforming activity. In order to analyse the conversion of the model compounds fed toghether in the mixture, the corresponding values are collected in Table 3. Appart from the unconverted fed compounds, acetone was detected in the condensate stream in concentrations between 1.0 and $4.0 \mathrm{wt} \%$, as a consequence of ketonization of acetic acid or hydrodeoxygenation of hydroxyacetone. In general, conversion varies in the order: HA $>$ AA $>$ Fur $>$ Ph. Contrary to the results obtained in Section 2.2, despite its lower carbon number, AA conversion is lower than HA. However, it must be taken into account that acetic acid can be formed as an intermediate during Fur steam reforming [66], which would increase its content in the condensate stream, leading to lower conversion values. With this 
exception, reforming of the mixture confirms the lower reactivity of molecules with increasing carbon number and aromaticity.

Table 3. Conversion ( $\mathrm{mol} \%$ ) of model compounds in the reforming of bio-oil aqueous fraction surrogate using the Ni-M/SBA-15 catalysts at time-on-stream (TOS) $=5 \mathrm{~h}$.

\begin{tabular}{ccccc}
\hline Catalyst & AA & HA & Fur & Ph \\
\hline Ni/SBA-15 & $87.6 \pm 1.4$ & $99.5 \pm 0.0$ & $77.4 \pm 3.0$ & $69.9 \pm 2.6$ \\
Ni-Cu/SBA-15 & $80.4 \pm 2.2$ & $96.5 \pm 0.4$ & $84.7 \pm 2.1$ & $74.0 \pm 2.3$ \\
Ni-Co/SBA-15 & $99.5 \pm 0.1$ & $100 \pm 0.0$ & $97.9 \pm 0.3$ & $89.5 \pm 0.9$ \\
Ni-Cr/SBA-15 & $98.4 \pm 0.2$ & $99.9 \pm 0.0$ & $95.5 \pm 0.6$ & $91.5 \pm 0.7$ \\
\hline
\end{tabular}

Product distribution in the gas outlet stream is shown in Figure 8, as mol \% in dry basis. Hydrogen content was similar, above $56 \mathrm{~mol} \%$, for all catalysts, except in the case of Ni-Cu/SBA-15 sample, which only reached $52 \mathrm{~mol} \%$. Compared to the steam reforming of single model compounds, hydrogen production is lower in the reforming of the model bio-oil aqueous fraction since the $\mathrm{S} / \mathrm{C}$ ratio is lower, which implies less $\mathrm{OH}^{*}$ or $\mathrm{O}^{*}$ intermediates (formed from water under reaction conditions) available to react with the $\mathrm{CH}_{\mathrm{x}}{ }^{*}$ or $\mathrm{C}^{*}$ species. This is supported by the fact that higher $\mathrm{CH}_{4}$ amounts are found among the gaseous products in comparison to the steam reforming of the single model compunds. Since hydrogenation of $\mathrm{CH}_{x}{ }^{*}$ and $\mathrm{C}^{*}$ to $\mathrm{CH}_{4}$ compete with the reaction of these intermediates with $\mathrm{OH}^{*}$ or $\mathrm{O}^{*}$, lower $\mathrm{S} / \mathrm{C}$ ratio would favour hydrogenation. As a consequence, lower $\mathrm{CO}_{2} / \mathrm{CO}$ ratios are also found in the reactor outlet stream, with values around 1 . Comparing catalysts, the lower hydrogen content in the products stream when using $\mathrm{Ni}-\mathrm{Cu} / \mathrm{SBA}-15$ is accompanied by higher $\mathrm{CH}_{4}$ amount, which indicates lower capacity of this sample to activate the water molecules.

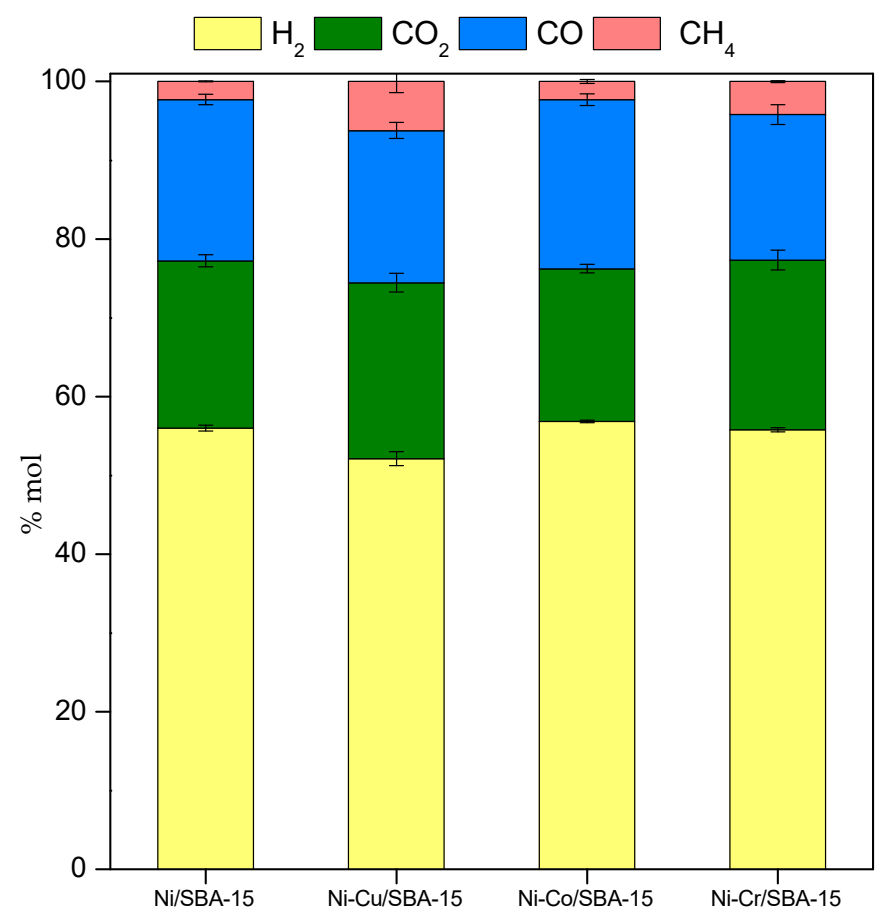

Figure 8. Gaseous products distribution (dry basis) obtained from reforming of model bio-oil aqueous fraction over Ni-M/SBA-15 catalysts.

The derivative thermograms of the used catalysts are displayed in Figure 9, together with the coke formation rate measured by TGA. Similarly to the steam reforming of the model compounds, the coking rate varies in the order: Ni-Cu/SBA-15 > Ni/SBA-15 > Ni-Co/SBA-15 > Ni-Cr/SBA-15. It must be highlighted the low carbon deposition on the Ni-Cr/SBA-15 catalyst, achieving a reduction of 
around eight 8 times compared to bare Ni/SBA-15 material. As expected, the carbon deposition is higher than that measured in the model compounds' steam reforming, due to the low water content in the bio-oil aqueous fraction, which implies unfavoured gasification of the $C^{*}$ intermediate species. On the other hand, the DTG profiles in Figure 8 show that the oxidation of coke takes place between 450 and $625^{\circ} \mathrm{C}$, indicating that carbon fibres were formed over the catalysts. Except for the Ni-Cr/SBA-15 sample, $\mathrm{T}_{\max }$ are above $565^{\circ} \mathrm{C}$, indicative of high condensation degree of the carbon deposits, which have been reported as the cause of Ni blocking [63]. Formation of highly condensed coke would be favoured by low S/C ratio, as a consequence lower carbon gasification rate at the expense of further dissociation of hydrocarbon intermediate species into carbon atoms. As a result, deactivation could be observed in the Ni-Cu/SBA-15 and Ni/SBA-15 samples within $5 \mathrm{~h}$ TOS. Catalytic activity and stability are significantly affected by the $\mathrm{Ni}-\mathrm{Cu}$ composition. Under dry methane reforming conditions at $600{ }^{\circ} \mathrm{C}$, Song et al. [38] reported that $\mathrm{Ni}-\mathrm{Cu} / \mathrm{Mg}(\mathrm{Al}) \mathrm{O}$ catalysts with $\mathrm{Cu} / \mathrm{Ni}$ ratios between 0.25 and 0.5 showed high activity and stability due to the formation of a $\mathrm{Ni}-\mathrm{Cu}$ alloy, whereas those samples with lower and higher $\mathrm{Cu} / \mathrm{Ni}$ ratios suffered from rapid deactivation because the nature of coke deposition varies significantly with $\mathrm{Ni}-\mathrm{Cu}$ composition. In our case, $\mathrm{Ni}-\mathrm{Cu} / \mathrm{SBA}-15(\mathrm{Cu} / \mathrm{Ni}=0.25)$ catalyst used in the steam reforming of bio-oil model compounds may be far from the $\mathrm{Cu} / \mathrm{Ni}$ ratio necessary to reduce coke deposition over $\mathrm{Ni} / \mathrm{SBA}-15$. In the case of the Ni-Co/SBA-15 catalyst, the fact that Co is also active in reforming reactions implies the higher active surface needed to be blocked before noticing deactivation. In addition, although the type of coke has a role in deactivation, high carbon deposition can lead to loss of the support porosity, blocking of pores and loss of the active surface inside the support pores.

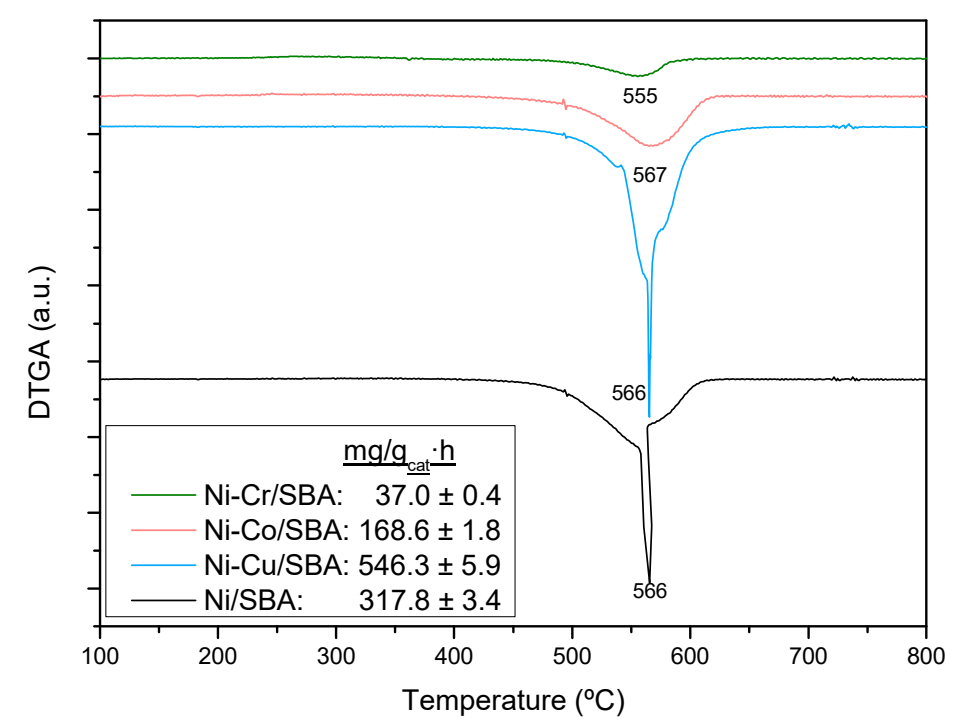

Figure 9. Derivative thermogravimetric analyses (airflow) of the Ni-M/SBA-15 catalysts used in the reforming of model bio-oil aqueous fraction.

The beneficial effect in coke resistance by $\mathrm{Cr}$ addition to $\mathrm{Ni} / \mathrm{SBA}-15$ catalyst can be ascribed to the small Ni crystallites, since the smaller the crystals, the more the initiation of carbon nucleation is impeded [67]. In addition, $\mathrm{Cr}$ addition to Ni catalysts below certain loadings has also been suggested to rearrange the $\mathrm{Ni}$ crystal plane and alter $\mathrm{Ni}$ electronic properties in such a way that the encapsulation of nickel by inactive carbon filaments is reduced [45].

\section{Experimental}

\subsection{Catalyst Synthesis and Characterization}

A series of catalysts were prepared to study the effect of the addition of $\mathrm{Cu}, \mathrm{Co}$ and $\mathrm{Cr}$ to $\mathrm{Ni} / \mathrm{SBA}-15$ catalyst (Ni: $15 \mathrm{wt} \%$ ). The synthesis of SBA-15 was carried out by the hydrothermal 
method as described by Zhao et al. [68] with air calcination at $550{ }^{\circ} \mathrm{C}$ in static conditions for $5 \mathrm{~h}$ at a heating rate of $1.8^{\circ} \mathrm{C} / \mathrm{min}$ carried out to eliminate the template agent. Catalysts are denoted as $\mathrm{Ni}-\mathrm{M} / \mathrm{SBA}-15$, where $\mathrm{M}$ are $\mathrm{Cu}, \mathrm{Co}$ or $\mathrm{Cr}$. The loading of the second metal in modified catalysts is $4 \mathrm{wt} \%$. Both $\mathrm{Ni}$ and the second metal were incorporated by incipient wetness co-impregnation of the corresponding nitrates precursors on SBA-15 support, with subsequent calcination at $600{ }^{\circ} \mathrm{C}$ for $5 \mathrm{~h}$ with a heating rate of $1.8^{\circ} \mathrm{C} / \mathrm{min}$. Calcination temperature was selected after TG analyses of the impregnated materials, in order to guarantee the decomposition of the corresponding precursors during the calcination step.

Catalysts were characterized by inductively coupled plasma atomic emission spectroscopy (ICP-AES), X-ray powder diffraction (XRD), hydrogen temperature programmed reduction (TPR) and nitrogen physisorption analysis $\left(\mathrm{N}_{2}-\mathrm{BET}\right)$.

ICP-AES technique was used to determine the metal content in the catalysts. Analyses of the samples, previously dissolved by acidic digestion with $\mathrm{H}_{2} \mathrm{SO}_{4}$ and $\mathrm{HF}$, were performed on a Varian VISTA-PRO AX CCD simultaneous ICP-AES apparatus.

XRD was used to determine the supports porous mesostructure and catalysts' crystalline phases (according to the Joint Committee on Powder Diffraction Standards-JCPDS index), as well as the mean metallic crystallite diameters calculated by Scherrer equation. Data were acquired on a Philips $X^{\prime}$ Pert PRO diffractometer, using $\mathrm{Cu} \mathrm{K} \alpha$ radiation, a $2 \theta$ increment step of $0.020^{\circ}$ and a collection time of $2 \mathrm{~s}$.

TPR was used to analyze the reducibility of the samples and obtain information about metal-support interaction. Measurements of the samples were performed on a Micromeritics AUTOCHEM 2910, placing the catalyst in a fixed-bed quartz tube under $10 \% \mathrm{H}_{2}$ in argon flow ( $35 \mathrm{~mL} / \mathrm{min}$ ) with a heating rate of $5{ }^{\circ} \mathrm{C} / \mathrm{min}$ from 25 to $900^{\circ} \mathrm{C}$. Effluent gas is forced to flow through a cold trap to remove water produced before reaching the thermal conductivity detector (TCD). Samples were previously degasified under dry argon flow $(35 \mathrm{~mL} / \mathrm{min})$ at $110^{\circ} \mathrm{C}$ for $30 \mathrm{~min}$ with a heating rate of $15^{\circ} \mathrm{C} / \mathrm{min}$.

Textural properties were measured by $\mathrm{N}_{2}$ adsorption/desorption analyses at $77 \mathrm{~K}$. using a Micromeritics TRISTAR 3000 sorptometer. Prior to the nitrogen-adsorption, samples were outgassed under vacuum at $200{ }^{\circ} \mathrm{C}$ for $4 \mathrm{~h}$. Surface areas were calculated according to BET method.

\subsection{Catalytic Tests}

The experimental installation where steam reforming tests were accomplished was a MICROACTIVITY-PRO unit (PID Eng\&Tech. S.L.), which consists of a fixed-bed tubular reactor in stainless steel 316 (i.d. $=9.2 \mathrm{~mm}, \mathrm{~L}=300 \mathrm{~mm}$ ) located inside an electric oven of low thermal inertia, where temperature inside the catalytic bed is measured by means of a thermocouple. All the components are placed inside a hot box in stainless steel 316 with a convector of hot air at $200{ }^{\circ} \mathrm{C}$ to prevent the condensation of volatile products in the pipes and to preheat the reactants efficiently. The liquid reaction mixture is fed by means of a GILSON 307 piston pump $(0.01-5 \mathrm{~mL} / \mathrm{min}, 400 \mathrm{bar})$ and passing through an evaporator before mixing with the preheated carrier gas $\left(\mathrm{N}_{2}\right)$ and entering the reactor. At the reactor outlet, there is a thermoelectric unit to condense and separate condensable vapors. A schematic diagram of this setup is shown in Figure 10.

The catalyst (300 mg, undiluted with inert material) was placed inside the reactor. Before testing, catalyst was in situ reduced under flowing pure hydrogen $(30 \mathrm{~mL} / \mathrm{min})$ at $700{ }^{\circ} \mathrm{C}$ for $6.5 \mathrm{~h}$ with a heating rate of $2{ }^{\circ} \mathrm{C} / \mathrm{min}$. After the catalyst activation, the reaction temperature was fixed for each experiment at $600{ }^{\circ} \mathrm{C}$ and catalytic testing was carried out isothermally at atmospheric pressure under nitrogen-diluted conditions. A liquid reaction mixture of the corresponding model compound(s) (acetic acid, hydroxyacetone, furfural and/or phenol) and water was introduced at a flow rate of $0.075 \mathrm{~mL} / \mathrm{min}$, vaporized at $200{ }^{\circ} \mathrm{C}$ and further eluted by $\mathrm{N}_{2}(60 \mathrm{~mL} / \mathrm{min})$. These conditions were determined in previous experiments to ensure the absence of internal and external diffusion limitations. 


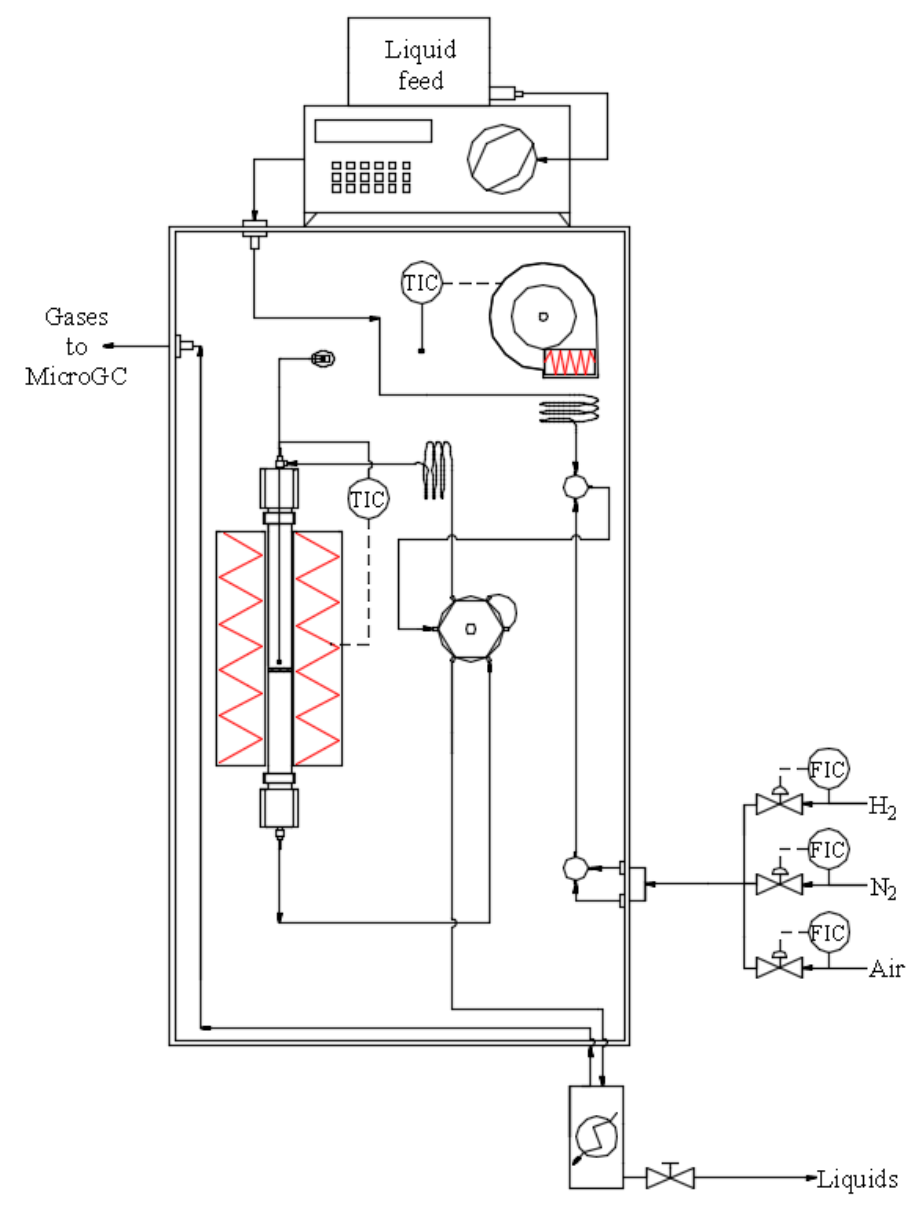

Figure 10. Schematic diagram of the catalytic testing setup [49].

In the case of the reforming of acetic acid (AA) and hydroxyacetone (HA), a water/compound molar ratio $=8$ was used. In the case of the reforming of phenol $(\mathrm{Ph})$ and furfural (Fur), since their solubility in water is limited $\left(82-83 \mathrm{~g} /\right.$ at $\left.20^{\circ} \mathrm{C}\right)$, a water/compound molar ratio $=66$ was used in order to guarantee homogeneous mixture. In addition, the steam reforming of a simulated bio-oil aqueous fraction was performed. The composition of the mixture was based on the aqueous fraction obtained in the catalytic fast-pyrolysis of partially de-ashed wheat straw using H-ZSM-5 [16], where bio-oil phases separation occurs without any water addition. In that investigation, carboxylic acids, ketones-ethers, furans and oxygenated aromatics were identified as the major compounds groups in aqueous fractions, accounting for the $85 \mathrm{wt} \%$ of the organic components, and the water content was $41 \mathrm{wt} \%$ (aqueous fraction composition not published; the composition was provided by the authors of the work [16] in the context of the RESTOENE 2 project). The most representative compound of each of the above-mentioned groups were selected. Thus, the mixture composition was $31 \mathrm{wt} \%$ acetic acid, $18 \mathrm{wt} \%$ hydroxyacetone, $6 \mathrm{wt} \%$ furfural and $4 \mathrm{wt} \%$ phenol in water.

The composition of the output gas stream was determined online in an Agilent 490 Micro-GC equipped with a Pora Plot U column $(10 \mathrm{~m})$, a Molecular Sieve 5A column $(20 \mathrm{~m})$ and thermal conductivity Detectors (TCD). Condensable vapors were trapped in the condenser at $4{ }^{\circ} \mathrm{C}$ and analyzed in the chromatograph Varian CP-3900 equipped with a CP-WAX 52 CB $(30 \mathrm{~m} \times 0.25 \mathrm{~mm}, \mathrm{DF}=0.25)$ column and flame ionization detector (FID).

Reactants conversion and products selectivity were calculated as follows:

$$
\mathrm{X}(\%)=\frac{F_{\text {reactant,in }}-F_{\text {reactant }, \text { out }}}{F_{\text {reactant }, \text { in }}} \cdot 100
$$




$$
S_{i}(m o l \%)=\frac{F_{i, o u t}}{\sum F_{i, o u t}} \cdot 100
$$

where $F_{\text {reactant, in }}$ and $F_{\text {reactant,out }}$ are the molar flow rates of the corresponding reactant (acetic acid, hydroxyacetone, furfural or phenol) at the inlet and outlet of the reactor, respectively. $F_{i, \text { out }}$ is the molar flow rate of the product $i$ species (hydrogen, carbon dioxide, carbon monoxide and methane) at the outlet of the reactor. The products outlet stream was analyzed several times along the reaction time (time-on-stream $=5 \mathrm{~h}$ ). In all experiments, the composition remained constant and thus the given reaction parameters are the averaged values.

Carbon deposited during reaction was evaluated through characterization of the used catalyst by thermogravimetric analyses (TGA). Measurements were performed in air flow on a TA instruments SDT 2960 thermobalance, with a heating rate of $5^{\circ} \mathrm{C} / \mathrm{min}$ up to $800^{\circ} \mathrm{C}$. The value of coke deposition is given as:

$$
C_{\text {dep }}(w t \%)=\frac{m_{\text {coke }}}{m_{\text {used catalyst }}} \cdot 100
$$

\subsection{Thermodynamic Calculations}

The thermodynamic equilibrium of a closed system with specific temperature and pressure is reached when the total Gibbs energy reaches a minimum. Thereby, the equilibrium composition of the outlet stream from the steam reforming of the model compounds (experimental feed compositions) was predicted at atmospheric pressure and different temperatures $\left(300-1000{ }^{\circ} \mathrm{C}\right)$ using the minimization of the Gibbs free energy method (Gibbs reactor) in Aspen HYSYS v10 simulation software. This software includes chemical component libraries as well as thermodynamic property prediction methods. Adding the compounds expected at the outlet gas stream is already enough to determine the equilibrium composition without the necessity of indicating a reaction set. Using the directions given by the software and according to other authors $[17,69,70]$, Peng-Robinson-Stryjek-Vera (PRSV) thermodynamic method was selected.

\section{Conclusions}

The Ni-M/SBA-15 catalysts $(\mathrm{M}: \mathrm{Cu}, \mathrm{Co}, \mathrm{Cr})$ prepared for this work are active in the steam reforming of the compounds typically contained in the bio-oil aqueous fractions, reaching high hydrogen production. However, while Ni-Co/SBA-15 and Ni-Cr/SBA-15 achieved conversions above $96 \%$ in all cases, Ni/SBA- 15 and Ni-Cu/SBA-15 samples suffered from deactivation. A relationship between loss of activity and coke formation rate could be established, although the nature of coke deposits also has an important role. The higher activity of Ni-Co/SBA-15 and Ni-Cr/SBA-15 has been ascribed to the presence of $\mathrm{Co}$ as an additional active metal and to the small $\mathrm{Ni}$ crystallites and strong interaction with the support in the Ni-Cr/SBA-15 sample.

When these catalysts were tested in the steam reforming of single model compounds (acetic acid, hydroxyacetone, furfural or phenol), a decrease in reactivity with increasing carbon number could be inferred, although higher $\mathrm{S} / \mathrm{C}$ ratio promoted higher conversion in the steam reforming of furfural and phenol. The main products' $\left(\mathrm{H}_{2}, \mathrm{CO}_{2}, \mathrm{CO}\right.$ and $\left.\mathrm{CH}_{4}\right)$ distribution, which slightly differs from the thermodynamic prediction by Gibbs energy minimization, could be explained by the complex reaction network implied in the process. A competition between hydrogenation and oxidation of carbon intermediate species will determine the product distribution. Catalysts with high capacity for $\mathrm{H}_{2} \mathrm{O}$ activation during the oxidation of these carbon intermediates will lead to higher $\mathrm{H}_{2}$ production by steam reforming, reducing $\mathrm{CH}_{4}$ formation.

The coking rate achieved in the steam reforming of model compounds varied in the order hydroxyacetone $>$ acetic acid $>$ furfural $>$ phenol, as a consequence of the nature of the reactant (carbon number and aromaticity) and the $\mathrm{S} / \mathrm{C}$ ratio, but deactivation also depends on the nature of coke. In this sense, a more graphitic coke was formed in the phenol steam reforming, while a poorly evolved coke was predominant with furfural. 
In the steam reforming of a surrogate of the aqueous fraction obtained in the catalytic fast-pyrolysis of de-ashed wheat straw, with S/C lower than stoichiometric, the superior catalytic behavior of Ni-Co/SBA-15 and Ni-Cr/SBA-15 was highlighted. However, Ni/SBA-15 and Ni-Cu/SBA-15 had worse behavior because both deactivated. In addition, the coking rate varied in the order: $\mathrm{Ni}-\mathrm{Cu} / \mathrm{SBA}-15>\mathrm{Ni} / \mathrm{SBA}-15>\mathrm{Ni}-\mathrm{Co} / \mathrm{SBA}-15>\mathrm{Ni}-\mathrm{Cr} / \mathrm{SBA}-15$. The low coke deposition on the $\mathrm{Ni}-\mathrm{Cr} / \mathrm{SBA}-15$ catalyst ( $~ 8$ times lower than $\mathrm{Ni} / \mathrm{SBA}-15)$ is attributed to small $\mathrm{Ni}$ crystallites avoiding the formation of the intermediary surface species of coke deposition, which also led to poorly condensed coke. On the contrary, the predominance of aged coke with high graphitization degree has been identified as the cause for the loss of conversion of $\mathrm{Ni}-\mathrm{Cu} / \mathrm{SBA}-15$ sample.

Author Contributions: Conceptualization, J.A.C. and A.C.; Methodology, A.J.V.; Validation, A.J.V.; Investigation, L.G.-M. and P.J.M.; Writing-Original Draft Preparation, L.G.-M., P.J.M. and A.J.V.; Writing-Review \& Editing, A.J.V., J.A.C. and A.C.; Supervision, A.J.V., J.A.C. and A.C.; Project Administration, J.A.C. and A.C.; Funding Acquisition, J.A.C. and A.C.

Funding: The authors acknowledge the financial support from the "Comunidad Autónoma de Madrid" through the RESTOENE2 project (S2013/MAE-2882) and from the "Ministerio de Economía y Competitividad" through the project CTQ2013-44447-R. The authors also thank to the IMDEA Energy Institute for supplying the results from the MS-GC analyses of the bio-oil aqueous fraction.

Conflicts of Interest: The authors declare no conflict of interest.

\section{References}

1. Nashawi, I.S.; Malallah, A.; Al-Bisharah, M. Forecasting world crude oil production using multicyclic Hubbert model. Energy Fuels 2010, 24, 1788-1800. [CrossRef]

2. Lior, N. Sustainable energy development: The present (2009) situation and possible paths to the future. Energy 2010, 35, 3976-3994. [CrossRef]

3. Marino, C.; Nucara, A.; Pietrafesa, M.; Pudao, A. An energy self-sufficient public building using integrated renewable sources and hydrogen storage. Energy 2013, 57, 95-105. [CrossRef]

4. Ajanovic, A. Renewable fuels-A comparative assessment from economic, energetic and ecological point-of-view up to 2050 in EU-countries. Renew. Energy 2013, 60, 733-738. [CrossRef]

5. Wang, K.; Zhang, J.; Tang, L.; Zhang, H.; Zhang, G.; Yang, X.; Liu, P.; Mao, Z. Establishment and assessment of a novel cleaner production process of corn grain fuel ethanol. Bioresour. Technol. 2013, 148, 453-460. [CrossRef] [PubMed]

6. Gökgöz, F.; Güvercin, M.T. Energy security and renewable energy efficiency in EU. Renew. Sustain. Energy Rev. 2018, 96, 226-239. [CrossRef]

7. Zhang, L.; Hu, X.; Hu, K.; Hu, C.; Zhang, Z.; Liu, Q.; Hu, S.; Xiang, J.; Wang, Y.; Zhang, S. Progress in the reforming of bio-oil derived carboxylic acids for hydrogen generation. J. Power Sources 2018, 403, 137-156. [CrossRef]

8. Santori, G.; DiNicola, G.; Moglie, M.; Polonara, F. A review analyzing the industrial biodiesel production practice starting from vegetable oil refining. Appl. Energy 2012, 92, 109-132. [CrossRef]

9. Arregi, A.; Amutio, M.; Lopez, G.; Bilbao, J.; Olazar, M. Evaluation of thermochemical routes for hydrogen production from biomass: A review. Energ. Convers. Manag. 2018, 165, 696-719. [CrossRef]

10. Vizcaíno, A.J.; Carrero, A.; Calles, J.A. Hydrogen Production from Bioethanol. In Hydrogen Production: Prospects and Processes; Honnery, D.R., Moriarty, P., Eds.; Nova Science Publishers, Inc.: New York, NY, USA, 2012; pp. 247-294. ISBN 978-1-62100-246-8.

11. Vizcaíno, A.J.; Carrero, A.; Calles, J.A. Comparison of ethanol steam reforming using Co and Ni catalysts supported on SBA-15 modified by Ca and Mg. Fuel Process. Technol. 2016, 146, 99-109. [CrossRef]

12. Carrero, A.; Vizcaíno, A.J.; Calles, J.A.; García-Moreno, L. Hydrogen production through glycerol steam reforming using Co catalysts supported on SBA-15 doped with Zr, Ce and La. J. Energy Chem. 2017, 26, 42-48. [CrossRef]

13. Trane, R.; Dahl, S.; Skjøth-Rasmussen, M.S.; Jensen, A.D. Catalytic steam reforming of bio-oil. Int. J. Hydrogen Energy 2012, 37, 6447-6472. [CrossRef] 
14. Rodrigues, A.; Bordado, J.C.; dos Santos, R.G. Upgrading the Glycerol from Biodiesel Production as a Source of Energy Carriers and Chemicals-A Technological Review for Three Chemical Pathways. Energies 2017, 10, 1817. [CrossRef]

15. Xiu, S.; Shahbazi, A. Bio-oil production and upgrading research: A review. Renew. Sustain. Energy Rev. 2012, 16, 4406-4414. [CrossRef]

16. Fermoso, J.; Hernando, H.; Jiménez-Sánchez, S.; Lappas, A.A.; Heracleous, E.; Pizarro, P.; Coronado, J.M.; Serrano, D.P. Bio-oil production by lignocellulose fast-pyrolysis: Isolating and comparing the effects of indigenous versus external catalysts. Fuel Process. Technol. 2017, 167, 563-574. [CrossRef]

17. Bimbela, F.; Ábrego, J.; Puerta, R.; García, L.; Arauzo, J. Catalytic steam reforming of the aqueous fraction of bio-oil using Ni-Ce/Mg-Al catalysts. Appl. Catal. B-Environ. 2017, 209, 346-357. [CrossRef]

18. Lian, X.; Xue, Y.; Zhao, A.; Xu, G.; Han, S.; Yu, H. Progress on upgrading methods of bio-oil: A review. Int. J. Energy Res. 2017, 41, 1798-1816. [CrossRef]

19. Vagia, E.C.; Lemonidou, A.A. Thermodynamic analysis of hydrogen production via steam reforming of selected components of aqueous bio-oil fraction. Int. J. Hydrogen Energy 2007, 32, 212-223. [CrossRef]

20. Bimbela, F.; Oliva, M.; Ruiz, J.; García, L.; Arauzo, J. Catalytic steam reforming of model compounds of biomass pyrolysis liquids in fixed bed: Acetol and n-butanol. J. Anal. Appl. Pyrolysis 2009, 85, 204-213. [CrossRef]

21. Wang, S.; Cai, Q.; Zhang, F.; Li, X.; Zhang, L.; Luo, Z. Hydrogen production via catalytic reforming of the bio-oil model compounds: Acetic acid, phenol and hydroxyacetone. Int. J. Hydrogen Energy 2014, 39, 18675-18687. [CrossRef]

22. Koike, M.; Li, D.; Watanabe, H.; Nakagawa, K.; Tomishige, K. Comparative study on steam reforming of model aromatic compounds of biomass tar over $\mathrm{Ni}$ and Ni-Fe alloy nanoparticles. Appl. Catal. A-Gen. 2015, 506, 151-162. [CrossRef]

23. Ma, Z.; Xiao, R.; Zhang, H. Catalytic steam reforming of bio-oil model compounds for hydrogen-rich gas production using bio-char as catalyst. Int. J. Hydrogen Energy 2017, 42, 3579-3585. [CrossRef]

24. Yao, X.; Yu, Q.; Xie, H.; Duan, W.; Han, Z.; Liu, S.; Qin, Q. The production of hydrogen through steam reforming of bio-oil model compounds recovering waste heat from blast furnace slag. J. Therm. Anal. Calorim. 2018, 131, 2951-2962. [CrossRef]

25. Wang, S.; Wang, Q.; Jiang, X.; Han, X.; Ji, H. Compositional analysis of bio-oil derived from pyrolysis of seaweed. Energy Conv. Manag. 2013, 68, 273-280. [CrossRef]

26. Zhang, S.; Yan, Y.; Li, T.; Ren, Z. Upgrading of liquid fuel from the pyrolysis of biomass. Bioresour. Technol. 2005, 96, 545-550. [CrossRef] [PubMed]

27. Hu, X.; Lu, G. Inhibition of methane formation in steam reforming reactions through modification of $\mathrm{Ni}$ catalyst and the reactants. Green Chem. 2009, 11, 724-732. [CrossRef]

28. Vizcaíno, A.J.; Carrero, A.; Calles, J.A. Ethanol steam reforming on Mg-and Ca-modified Cu-Ni/SBA-15 catalysts. Catal. Today 2009, 146, 63-70. [CrossRef]

29. Carrero, A.; Calles, J.A.; Vizcaíno, A.J. Effect of $\mathrm{Mg}$ and $\mathrm{Ca}$ addition on coke deposition over $\mathrm{Cu}-\mathrm{Ni} / \mathrm{SiO} 2$ catalysts for ethanol steam reforming. Chem. Eng. J. 2010, 163, 395-402. [CrossRef]

30. Calles, J.A.; Carrero, A.; Vizcaíno, A.J.; García-Moreno, L. Hydrogen production by glycerol steam reforming over SBA-15-supported nickel catalysts: Effect of alkaline earth promoters on activity and stability. Catal. Today 2014, 227, 198-206. [CrossRef]

31. Jeon, J.; Nam, S.; Ko, C.H. Rapid evaluation of coke resistance in catalysts for methane reforming using low steam-to-carbon ratio. Catal. Today 2018, 309, 140-146. [CrossRef]

32. He, Z.; Jiao, Y.; Wang, J.; Chen, Y. Bi-functional composite oxides $\mathrm{M}(\mathrm{Na}, \mathrm{K})-\mathrm{Ni} / \mathrm{La}-\mathrm{Al}_{2} \mathrm{O}_{3}$ catalysts for steam reforming of n-decane. Fuel 2018, 212, 193-201. [CrossRef]

33. Nabgan, W.; Abdullah, T.A.T.; Mat, R.; Nabgan, B.; Gambo, Y.; Moghadamian, K. Acetic acid-phenol steam reforming for hydrogen production: Effect of different composition of $\mathrm{La}_{2} \mathrm{O}_{3}-\mathrm{Al}_{2} \mathrm{O}_{3}$ support for bimetallic Ni-Co catalyst. J. Environ. Chem. Eng. 2016, 4, 2765-2773. [CrossRef]

34. Calles, J.A.; Carrero, A.; Vizcaíno, A.J. Ce and La modification of mesoporous Cu-Ni/SBA-15 catalysts for hydrogen production through ethanol steam reforming. Microporous Mesoporous Mater. 2009, 119, $200-207$. [CrossRef]

35. Calles, J.A.; Carrero, A.; Vizcaíno, A.J.; Lindo, M. Effect of $\mathrm{Ce}$ and $\mathrm{Zr}$ addition to $\mathrm{Ni} / \mathrm{SiO}_{2}$ catalysts for hydrogen production through ethanol steam reforming. Catalysts 2015, 5, 58-76. [CrossRef] 
36. Vizcaíno, A.J.; Carrero, A.; Calles, J.A. Hydrogen production by ethanol steam reforming over Cu-Ni supported catalysts. Int. J. Hydrogen Energy 2007, 32, 1450-1461. [CrossRef]

37. Carrero, A.; Calles, J.A.; Vizcaíno, A.J. Hydrogen production by ethanol steam reforming over Cu-Ni/SBA-15 supported catalysts prepared by direct synthesis and impregnation. Appl. Catal. A-Gen. 2007, 327, 82-94. [CrossRef]

38. Song, K.; Lu, M.; Xu, S.; Chen, C.; Zhan, Y.; Li, D.; Au, C.; Jiang, L.; Tomishige, K. Effect of alloy composition on catalytic performance and coke-resistance property of $\mathrm{Ni}-\mathrm{Cu} / \mathrm{Mg}(\mathrm{Al}) \mathrm{O}$ catalysts for dry reforming of methane. Appl. Catal. B Environ. 2018, 239, 324-333. [CrossRef]

39. Pant, K.K.; Mohanty, P.; Agarwal, S.; Dalai, A.K. Steam reforming of acetic acid for hydrogen production over bifunctional Ni-Co catalysts. Catal. Today 2013, 207, 36-43. [CrossRef]

40. Zhang, Y.; Li, W.; Zhang, S.; Xu, Q.; Yan, Y. Steam Reforming of Bio-Oil for Hydrogen Production: Effect of Ni-Co Bimetallic Catalysts. Chem. Eng. Technol. 2012, 35, 302-308. [CrossRef]

41. Assaf, P.G.; Nogueira, F.G.E.; Assaf, E.M. Ni and Co catalysts supported on alumina applied to steam reforming of acetic acid: Representative compound for the aqueous phase of bio-oil derived from biomass. Catal. Today 2013, 213, 2-8. [CrossRef]

42. Horlyck, J.; Lawrey, C.; Lovell, E.C.; Amal, R.; Scott, J. Elucidating the impact of Ni and Co loading on the selectivity of bimetallic NiCo catalysts for dry reforming of methane. Chem. Eng. J. 2018, 352, 572-580. [CrossRef]

43. Garcia, L.; French, R.; Czernik, S.; Chornet, E. Catalytic steam reforming of bio-oils for the production of hydrogen: Effects of catalyst composition. Appl. Catal. A-Gen. 2000, 201, 225-239. [CrossRef]

44. Xu, L.; Duan, L.; Tang, M.; Liu, P.; Ma, X.; Zhang, Y.; Harris, H.G.; Fan, M. Catalytic $\mathrm{CO}_{2}$ reforming of $\mathrm{CH}_{4}$ over Cr-promoted $\mathrm{Ni}$ /char for $\mathrm{H}_{2}$ production. Int. J. Hydrogen Energy 2014, 39, 10141-10153. [CrossRef]

45. Bangala, D.N.; Abatzoglou, N.; Chornet, E. Steam reforming of naphthalene on Ni-Cr/Al2O3 catalysts doped with $\mathrm{MgO}, \mathrm{TiO}_{2}$, and $\mathrm{La}_{2} \mathrm{O}_{3}$. AIChE J. 1998, 44, 927-936. [CrossRef]

46. Bui, Q.T.P.; Kim, Y.; Yoon, S.P.; Hana, J.; Ham, H.C.; Nam, S.W.; Yoon, C.W. Steam reforming of simulated biogas over plate Ni-Cr catalysts: Influence of pre-oxidation on catalytic activity. Appl. Catal. B Environ. 2015, 166-167, 335-344. [CrossRef]

47. Odedairo, T.; Ma, J.; Chen, J.; Wang, S.; Zhu, Z. Influences of doping Cr/Fe/Ta on the performance of $\mathrm{Ni} / \mathrm{CeO}_{2}$ catalyst under microwave irradiation in dry reforming of $\mathrm{CH}_{4}$. J. Solid State Chem. 2016, 233, 166-177. [CrossRef]

48. Yang, X.; Wang, Y.; Wang, Y. Significantly improved catalytic performance of Ni-based MgO catalyst in steam reforming of phenol by inducing mesostructure. Catalysts 2015, 5, 1721-1736. [CrossRef]

49. Carrero, A.; Calles, J.A.; García-Moreno, L.; Vizcaíno, A.J. Production of renewable hydrogen from glycerol steam reforming over bimetallic $\mathrm{Ni}-(\mathrm{Cu}, \mathrm{Co}, \mathrm{Cr})$ catalysts supported on SBA-15 silica. Catalysts 2017, 7, 55. [CrossRef]

50. Ertl, G.; Knözinger, H.; Weitkamp, J. Handbook of Heterogeneous Catalysis; Wiley-VHC: Weinheim, Germany, 1997; Volume 2, pp. 446-450. ISBN 3-527-29212-8.

51. Resende, K.A.; Ávila-Neto, C.N.; Rabelo-Neto, R.C.; Noronha, F.B.; Hori, C.E. Thermodynamic analysis and reaction routes of steam reforming of bio-oil aqueous fraction. Renew. Energy 2015, 80, 166-176. [CrossRef]

52. Montero, C.; Oar-Arteta, L.; Remiro, A.; Arandia, A.; Bilbao, J.; Gayubo, A.G. Thermodynamic comparison between bio-oil and ethanol steam reforming. Int. J. Hydrogen Energy 2015, 40, 15963-15971. [CrossRef]

53. Sahebdelfar, S. Steam reforming of propionic acid: Thermodynamic analysis of a model compound for hydrogen production from bio-oil. Int. J. Hydrogen Energy 2017, 42, 16386-16395. [CrossRef]

54. Trane-Restrup, R.; Resasco, D.E.; Jensen, A.D. Steam reforming of light oxygenates. Catal. Sci. Technol. 2013, 3, 3292-3302. [CrossRef]

55. Lemonidou, A.A.; Vagia, E.C.; Lercher, J.A. Acetic Acid Reforming over Rh Supported on $\mathrm{La}_{2} \mathrm{O}_{3} / \mathrm{CeO}_{2}-\mathrm{ZrO}_{2}$ : Catalytic Performance and Reaction Pathway Analysis. ACS Catal. 2013, 3, 1919-1928. [CrossRef]

56. Wang, S.; Li, X.; Zhang, F.; Cai, Q.; Wang, Y.; Luo, Z. Bio-oil catalytic reforming without steam addition: Application to hydrogen production and studies on its mechanism. Int. J. Hydrogen Energy 2013, 38, 16038-16047. [CrossRef] 
57. Li, Z.; Hu, X.; Zhang, L.; Liu, S.; Lu, G. Steam reforming of acetic acid over $\mathrm{Ni} / \mathrm{ZrO}_{2}$ catalysts: Effects of nickel loading and particle size on product distribution and coke formation. Appl. Catal. A Gen. 2012, 417-418, 281-289. [CrossRef]

58. Li, X.; Wang, S.; Zhu, Y.; Yang, G.; Zheng, P. DFT study of bio-oil decomposition mechanism on a Co stepped surface: Acetic acid as a model compound. Int. J. Hydrogen Energy 2015, 40, 330-339. [CrossRef]

59. Wang, S.; Zhang, F.; Cai, Q.; Li, X.; Zhu, L.; Wang, Q.; Luo, Z. Catalytic steam reforming of bio-oil model compounds for hydrogen production over coal ash supported Ni catalyst. Int. J. Hydrogen Energy 2014, 39, 2018-2025. [CrossRef]

60. Matas Güell, B.; Babich, I.V.; Lefferts, L.; Seshan, K. Steam reforming of phenol over Ni-based catalysts-A comparative study. Appl. Catal. B Environ. 2011, 106, 280-286. [CrossRef]

61. Ashok, J.; Subrahmanyam, M.; Venugopal, A. Hydrotalcite structure derived Ni-Cu-Al catalysts for the production of $\mathrm{H}_{2}$ by $\mathrm{CH}_{4}$ decomposition. Int. J. Hydrogen Energy 2008, 33, 2704-2713. [CrossRef]

62. Artetxe, M.; Nahil, M.A.; Olazar, M.; Williams, P.T. Steam reforming of phenol as biomass tar model compound over $\mathrm{Ni} / \mathrm{Al}_{2} \mathrm{O}_{3}$ catalyst. Fuel 2016, 184, 629-636. [CrossRef]

63. Montero, C.; Ochoa, A.; Castaño, P.; Bilbao, J.; Gayubo, A.G. Monitoring $\mathrm{Ni}^{0}$ and coke evolution during the deactivation of a Ni/ $\mathrm{La}_{2} \mathrm{O}_{3}-\alpha \mathrm{Al}_{2} \mathrm{O}_{3}$ catalyst in ethanol steam reforming in a fluidized bed. J. Catal. 2015, 331, 181-192. [CrossRef]

64. Bimbela, F.; Oliva, M.; Ruiz, J.; García, L.; Arauzo, J. Hydrogen production via catalytic steam reforming of the aqueous fraction of bio-oil using nickel-based coprecipitated catalysts. Int. J. Hydrogen Energy 2013, 38, 14476-14487. [CrossRef]

65. Liu, Q.; Zhong, Z.; Gu, F.; Wang, X.; Lu, X.; Li, H.; Xu, G.; Su, F. CO methanation on ordered mesoporous $\mathrm{Ni}-\mathrm{Cr}-\mathrm{Al}$ catalysts: Effects of the catalyst structure and $\mathrm{Cr}$ promoter on the catalytic properties. J. Catal. 2016, 337, 221-232. [CrossRef]

66. Trane-Restrup, R.; Jensen, A.D. Steam reforming of cyclic model compounds of bio-oil over Ni-based catalysts: Product distribution and carbon formation. Appl. Catal. B Env. 2015, 165, 117-127. [CrossRef]

67. Helveg, S.; Sehested, J.; Rostrup-Nielsen, J.R. Whisker carbon in perspective. Catal. Today 2011, 178, 42-46. [CrossRef]

68. Zhao, D.; Feng, J.; Huo, Q.; Melosh, N.; Fredrickson, G.H.; Chmelka, B.; Stucky, G. Triblock copolymer syntheses of mesoporous silica with periodic 50 to 300 angstrom pores. Science 1998, 279, 548-552. [CrossRef]

69. Remón, J.; Mercado, V.; García, L.; Arauzo, J. Effect of acetic acid, methanol and potassium hydroxide on the catalytic steam reforming of glycerol: Thermodynamic and experimental study. Fuel Process. Technol. 2015, 138, 325-336. [CrossRef]

70. Remón, J.; Broust, F.; Volle, G.; García, L.; Arauzo, J. Hydrogen production from pine and poplar bio-oils by catalytic steam reforming. Influence of the bio-oil composition on the process. Int. J. Hydrogen Energy 2015, 40, 5593-5608. [CrossRef]

(C) 2019 by the authors. Licensee MDPI, Basel, Switzerland. This article is an open access article distributed under the terms and conditions of the Creative Commons Attribution (CC BY) license (http://creativecommons.org/licenses/by/4.0/). 